Article

\title{
Eco-Efficiency of the Fisheries Value Chains in the Gambia and Mali
}

\author{
Angel Avadi 1,2,*(D) and Ivonne Acosta-Alba ${ }^{3,4}$ \\ 1 CIRAD, UPR Recyclage et risque, F-34398 Montpellier, France \\ 2 CIRAD, Université Montpellier, Recyclage et risque, F-34398 Montpellier, France \\ CIRAD, UMR Innovation, F-34398 Montpellier, France; ivonne_alba@orange.fr \\ 4 Evalivo, Sustainability Assessment of Food Systems, 02100 Saint Quentin, France \\ * Correspondence: angel.avadi@cirad.fr; Tel.: +33-4-67-61-59-67
}

check for

updates

Citation: Avadí, A.; Acosta-Alba, I. Eco-Efficiency of the Fisheries Value Chains in the Gambia and Mali. Foods 2021, 10, 1620. https://doi.org/ 10.3390 /foods 10071620

Academic Editors: Marian Kjellevold and Friederike Ziegler

Received: 15 June 2021

Accepted: 9 July 2021

Published: 13 July 2021

Publisher's Note: MDPI stays neutral with regard to jurisdictional claims in published maps and institutional affiliations.

Copyright: (C) 2021 by the authors Licensee MDPI, Basel, Switzerland. This article is an open access article distributed under the terms and conditions of the Creative Commons Attribution (CC BY) license (https:// creativecommons.org/licenses/by/ $4.0 /)$.

\begin{abstract}
The Gambian and Malian fisheries and fish processing value chains are predominantly artisanal and represent a key source of protein and livelihoods, yet their eco-efficiency has not been studied to date. A Life Cycle Assessment was used to estimate the associated environmental impacts of those value chains and provide information on the eco-efficiency indicators, which relate technical efficiencies to environmental impacts. The results showed that industrial Gambian fleets' fuel use efficiency is rather low as compared with the global mean fuel use intensity (landed fish/consumed fuel) for both small pelagics and demersal fish. In Mali, the fuel use intensity of motorised artisanal fisheries is lower than the mean values for artisanal inland fisheries in developing countries, but the important increase of frozen imported fish from fish farming multiplies the estimated impacts by four. The least energy-intensive fisheries (cast nets and stow nets in Gambia and opportunistic fishers in Mali) feature better eco-efficiency scores. Based on the identified sources of inefficiencies, we suggest improvements in the landing/processing infrastructure and fishing units' engines, coupled with technical and business training and improved processing methods, to ameliorate seafood ecoefficiency and a stronger recognition of the importance of the artisanal fisheries subsector to overcome challenges and improving resource management.
\end{abstract}

Keywords: environmental impacts; artisanal fisheries; fuel use intensity

\section{Introduction}

Reducing the environmental impact of our food system is a requirement to preserve natural resources and our ability to produce food and respond to a growing demand [1]. In the context of declining fish stocks, growing population and increasingly complex relations among actors in the fisheries sector [2], a value chain analysis revealed strategies that enhance the sustainability and competitiveness of all economic agents involved [3]. Particularly in Africa, as large populations depend on fisheries for food security and livelihoods, studies combining socioeconomic and environmental ecosystem concerns are valuable to decision-makers [4,5].

In Africa, fish is also the main animal protein source (36\%), and historically, this proportion has reached $40 \%$ for inland fish in the 1990s [6]. It has been recently estimated [7] that over 35 million coastal fishers live from this activity, with total landed catches worth 20 billion USD plus an additional 3.6 billion USD generated across value chains by the small-scale fishing sector alone. Nonetheless, the growth of fish supply in the region is generally lower than it should be to satisfy the growing demand [8].

The total fishery production in Africa was estimated at 9.4 Mt in 2010, 4.9 Mt of which were sourced from marine captures, $2.7 \mathrm{Mt}$ from inland water fisheries and about $1.4 \mathrm{Mt}$ from aquaculture [9]. The World Forum of Fishing Peoples estimated in 2017 that more than 60 million people rely on inland fisheries for at least part of their livelihood, and over $90 \%$ of inland waters are in Asia or Africa, while $55 \%$ of the catches are not identified 
by species [10]. The framework survey of inland fisheries conducted in 2012 by the West African Economic and Monetary Union showed that this subsector appears significant in terms of work, food self-sufficiency and economic value [11,12].

A multicriteria environmental assessment is the key to finding solutions and monitoring complex trade-offs and multiple ways for producers and consumers to reduce food's environmental impacts [13]. A Life Cycle Assessment (LCA) evaluates the environmental impacts of a product or a service, including all the steps from the extraction of raw materials to the final user, disposal or recycling. Technical inefficiencies in food systems are often studied with LCA as an ISO-standardised framework [14] accounting for all resource consumption and emissions associated with a production system, between the economic system and nature in terms of environmental impacts, modelling environmental mechanisms to estimate the associated impacts. Those potential impacts are expressed through environmental indicators, such as $\mathrm{tCO}_{2}$ equivalents emitted, which contribute to climate change and, thus, to damages to human health and ecosystem quality.

Eco-efficiency, as defined by the World Business Council for Sustainable Development [15], is a useful concept to simultaneously address the economic performance of a productive activity and its relative level of impacts on the environment, including effects on exploited ecosystems in the case of extractive activities such as fisheries. The link between eco-efficiency and cleaner production, including in fisheries, has long been established $[16,17]$. The economic performance of fisheries and dependent value chains such as fish processing, fishmeal, etc. is driven by technical efficiencies.

Efficiency in fisheries is usually gauged in terms of the fuel use intensity (i.e., the ratio of fuel consumption to landed unit of fish) [18-20]. Other indicators include ratios between produced and invested values; some examples include energy and protein-toenergy [21,22]. More complex approaches include, for instance, the Data Envelopment Analysis, a linear programming methodology used to determine the relative (distance to target) efficiencies of a set of multiple comparable units [23].

Several LCA studies have explored the eco-efficiency of crops [24-27], livestock [28,29] and seafood systems [30-32] but few at the value chain level [33-35]. The goal of this work is to assess the environmental impacts and eco-efficiency of the Gambian and Malian fisheriesbased value chains, to identify priorities for improvement and to offer recommendations aimed at improving the eco-efficiency and, thus, to reduce the environmental impacts of the concerned value chains while increasing their technical efficiency. An extensive mapping of the Gambian and Malian fisheries value chains was described by the authors [36-38]. As far as we know, the eco-efficiency of these fishery supply chains had not been explored before from such an angle, and, in general, LCA studies of African fisheries are seldom produced in contrast with other fisheries. The need for more publishing data on diverse seafood systems and countries has been highlighted in the literature [39].

This initiative intends to provide the evidence-based knowledge on the development impacts of value chain operations so as to assist decision-making for investment projects in agriculture/seafood and to facilitate sectorial policy dialogue. In such context, "value chain" refers to the network of economic agents or actors and their activities delivering a product or service, as understood in the context of the European Commission's Value Chain Analysis (VCA4D) framework [4,5]. This understanding of the term is interchangeable with "supply chain".

\section{Materials and Methods}

\subsection{The Gambian and Malian Fisheries Value Chains}

The Gambian fisheries value chain consists of a variety of fishing activities, dominated by "artisanal" (i.e., small-scale) production units and an important fish processing sector, which includes both artisanal and industrial transformation activities. The bulk of captures are destined for direct human consumption within the country, but a growing proportion is redirected to export-oriented processing, such as drying and smoking for direct human consumption in other countries and fishmeal production for indirect human consumption 
abroad. The most important species consist of small pelagics. Fishing vessels are highly specialised regarding fishing gears and targeted species.

Mali is a landlocked country described by the authors [40] as having one of the highest continental fishery productivities in the world. The Malian fisheries value chain is composed by actors that fulfil several activities (fishing, trading and processing) and by an important diversity of hydrological resources. The flood wave that annually runs through the Niger River changes the landscape, creating new fishing areas (e.g., floodplains, ponds, backwaters, etc.). Fishing activities are seasonally and geographically distributed with a great variability in catch the areas and species targeted. Fish is consumed either processed (smoked, dried, burned or oiled) or fresh. Many freshwater species are targeted, including catfishes and tilapias. Fishing in Mali is essentially artisanal, and in general, it is not specialised.

A complete inventory describing both value chains, their economic agents and products are needed as input for the environmental analysis. The primary data were collected during two fieldtrips in each country, carried out in 2019, and through a follow-up with key respondents.

\subsection{Environmental Analysis Framework}

LCA has widely been applied to study the environmental implications of seafood value chains [41]. The first step of LCA is to define the system boundaries and the goal and scope of the assessment. Then, an inventory of all input and output fluxes over the entire life cycle of the studied systems is established. The inventory was based on mainly relying on field-collected primary data (obtained via key informant interviews and structured questionnaires with both stakeholders and experts) and complemented with secondary data (scientific and grey literature). Based on the inventory, the calculation of relevant environmental indicators and interpretation of the results were the final steps.

\subsubsection{Goal and Scope}

The goal of the LCAs was to estimate and compare the environmental impacts of a system or a product-in the present work, the Gambian and Malian fisheries-based value chains. Two main functional units to express impacts were retained: $1 \mathrm{t}$ of fresh whole fish and $1 \mathrm{t}$ of processed fish product (e.g., frozen, dried or smoked fish and fish portions). These functional units have been widely used in comparative seafood LCAs [39,42]. The reference flows are the annual landings per vessel category for fisheries and the amount of fresh fish required to produce $1 \mathrm{t}$ of fish product for processing.

In LCA of fishery-based systems, including aquaculture and fish processing, special attention is given to inventory items, which are known to drive most impacts [39,41]. These items include energy consumption; fishing gear; feeds (aquaculture) and technical yields such as the fuel use intensity for fisheries, feed conversion ratio for aquaculture, fish-to-fishmeal yield for reduction industries and the fish-to-product yield for other fish processing.

Mass-weighted economic allocation was applied to assign fishery impacts between the landed target fish and by catch for fisheries featuring by catch. No impacts were allocated to fish residues from artisanal or industrial processing, as they are considered as wastes without a market price $[43,44]$. The technological scope encompasses the current technologies deployed in West Africa, and the temporal scope corresponds to the 2014-2018 period. The scope of the assessment was from cradle to market. 


\subsubsection{Inventory of Value Chains}

Representative units of production (UP), were constructed for each activity of the economic agents of the value chains (i.e., the various distinctive fisheries, artisanal and industrial processing and fish product distribution) for the most representative system types based on field data collection:

- Producers (artisanal and industrial fisheries, shellfish collection systems and fish farming for imported fish);

- Processors (artisanal drying, artisanal and industrial smoking, industrial freezing and fishmeal production);

- Distributors (in terms of fish transportation activities across trader types).

Ancillary systems, such as ice and fishing infrastructures (vessels and fishing gear), were also modelled. Background inventory data, including the provision of all fuels; grid electricity (Senegalese grid electricity retained as a proxy for the Gambian electricity provision); tap water and industrial inputs (chemicals, plastics and other materials) were obtained from ecoinvent v3.5 [45]. Scenarios of distribution were based on representative transport distances and means for both countries.

\subsubsection{Impact Assessment}

The Impact assessment method ReCiPe (2.2 Endpoint World H/A (Hierarchy/ Average)) was retained. Impacts were estimated for three areas of protection (AoP) based on many relevant impact categories [46] with different units (human health: disability-adjusted life years, ecosystems: species.yr and resources: USD). In ReCiPe, impacts on the AoP can be also expressed as dimensionless "points" (Pt) and combined into a single score after a normalisation and weighting step. These indicators only make sense in comparative contexts to express (a) the relative contribution of an impact category to the cumulative impacts of the product system on an AoP and (b) the cumulative environmental performance (impacts) of the product system.

The method Cumulative Energy Demand (CED) [47] was used to derive additional specific eco-efficiency indicators. This indicator includes renewable and not renewable energy used during the life cycle of products.

\subsection{Eco-Efficiency Assessment}

The VCA4D environmental analysis framework, based on LCA, was extended to assess the eco-efficiency of the studied value chains. Fuel use intensity (FUI), namely the ratio between landed fish and fuel consumed to catch and land the fish, is widely used as an indicator of fishery efficiency in a LCA, as it captures both the actual fishing effort as well as other components of the fishing activity, such as the fuel consumption associated with travel to and from fishing areas and even fuel-saving strategies and other skipper behaviours $[39,48]$. Fuel consumption and productive activities in general are determined in fisheries by multiple motivations of the fishers beyond simply profit maximisation [49].

Two additional indicators were used, energy return on investment (EROI) $[21,22,30]$ and protein-per-impact (PPI) $[22,35,50]$. The former refers to the ratio of energy embedded in a fish product to the industrial energy (CED) required to produce it (expressed, for instance, with respect to its edible yield), while the latter represents the ratio of proteins (as a proxy for nutritional value) delivered by a product to the potential environmental impacts estimated by the LCA, as described in reference [22]. The relation between energy and protein obtained from fish, especially regarding inland fisheries, has been highlighted in the literature [51,52]. The gross energy content (GEC) was computed from the lipid and protein contents, following the energy contents of those components and equations presented in FAO documents $[53,54]$. The lipid and protein contents, and edible yields, were retrieved from several FAO sources [54-57]. 


\section{Results}

\subsection{LCA of the Gambian and Malian Fisheries Value Chains}

\subsubsection{Life Cycle Inventory Analysis}

The system boundaries of the modelled systems are depicted in Figure 1. For the Gambian value chain, the main identified products were divided into two categories: on the one hand, fresh fish (small pelagic fish, demersal fish, shrimps and cephalopods from artisanal and industrial fleets) and, in the other, processed fish (dried fish, smoked fish, frozen fish, fish meal and braised-dried shellfish). In the Malian value chain, the products were less diversified, with fresh fish (for rural or urban markets from artisanal fishing) and processed fish (artisanal smoked fish for rural and urban markets and frozen, imported fish, including small pelagics or fish farming from Asia).

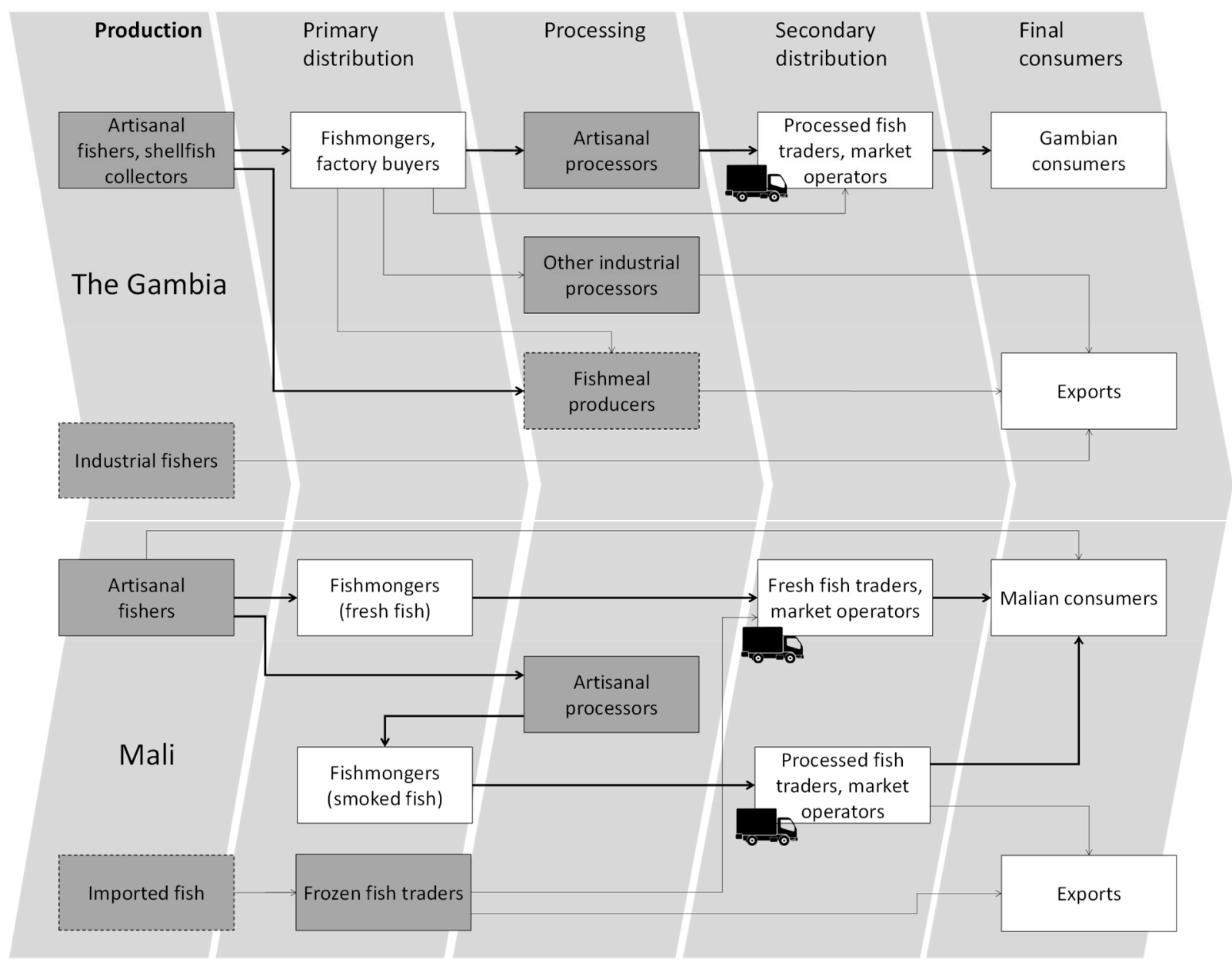

Figure 1. Simplified scheme of the Gambian and Malian fishery value chains (blocks in grey and transport icons represent systems modelled in the LCA; thicker lines represent more important flows; dotted boxes represent modelling based on secondary data and proxies.

For each of these products, three types of actors were modelled-namely, producers (artisanal and industrial fisheries and shellfish collection systems); processors (artisanal drying, artisanal and industrial smoking and industrial freezing) and distributors (modelled in terms of fish transport activities). The inventories were modelled based on field surveys and the literature, as presented in Table 1. 
Table 1. Life cycle inventories by the type of unit of production in the Gambian fisheries value chain.

\begin{tabular}{cl}
\hline Unit of Production (UP) Type & \multicolumn{1}{c}{ Life Cycle Inventory Items } \\
\hline & $\begin{array}{l}\text { Hull and engine materials, fishing gear, fuel and lubricating oil consumption, ice, bait and } \\
\text { refrigerant gases, antifouling paint and mean annual captures, landings and discards, as } \\
\text { recommended in the literature }[41,58,59] \text {. Two-thirds of solids in the antifouling paint were } \\
\text { assumed to be lost as antifouling emissions to the ocean, as usually assumed in fishery } \\
\text { LCAshing by fishing units } \\
\text { trawlers operating in the Gambia are Senegalese. }\end{array}$ \\
\hline
\end{tabular}

LCIs of shellfish collection are very basic, as no complex means of production are involved in

Shellfish collection that activity, except for dugout canoes, hand tools and fuel for braising. A 2-m-long dugout canoe weights up to $370 \mathrm{~kg}$, and the amount of fuel consumed per UP (shellfish harvester) adds up to $1.7 \mathrm{~m}^{3}$ wood per year (sourced from Senegal and from commercial operations) for processing $273 \mathrm{~kg}$ shellfish flesh per year for a yield of $91 \mathrm{~kg} /$ year of dried shellfish products.

Production of ice The production of ice for the artisanal fisheries is performed by both government-run and private plants. These plants produce between 1300 and $1600 \mathrm{t}$ ice per year, consuming between 59.1 and $77.5 \mathrm{kWh} / \mathrm{t}$ ice.

Fish processing

Fish processing, both artisanal and industrial, were modelled in terms of fuels consumption (liquid fuels and biomass), chemicals and packaging materials, product yields and water and waste generation, as recommended in the literature [41,59].

Based on the secondary data obtained from West African (e.g., Mauritania) and global literature [41,62-68], as Gambia-based Chinese-owned fishmeal plants failed to provide data. Technical features and efficiencies of plants were considered at a level between Peruvian fair

Fishmeal production average quality and residual plants, with a fish-to-fishmeal conversion ratio of 4.5 , and featuring direct drying fuelled by R500 residual fuel. The total amount of processed fish was computed based on the fish-to-fishmeal conversion ratio and export data, as all fishmeal is exported, and all exports are authorised by the Gambian Food Safety and Quality Authority (FSQA), which provided disaggregated data.

In the Gambia, distances are relatively modest. As the bulk (67\%) of artisanal landings destined for direct human consumption take place in the coastal landing sites, most of the fish is distributed through markets, and most of the population lives between the Atlantic coast and Farafenni, two transport distances that were estimated to represent the two main

Fish distribution scenarios for fish products transport: the 25-km Tanji-to-Brikama segment and the $150-\mathrm{km}$ Tanji-to-Farafenni segment. The impact of transporting fish upcountry was estimated based on these two reference distances; fish processing, both artisanal and industrial, was modelled in terms of fuel consumption (liquid fuels and biomass), chemicals and packaging materials, product yields and water and waste generation, as recommended in the literature $[41,59]$.

For the Malian value chain, the actors modelled included: producers (Malian artisanal fishers who were categorised following the proportion of fishing activities in their total income as opportunistic, part-time, diversified and full-time fishers and foreign artisanal producers and industrial fishers based on the case of the Gambia and fish farmers of tilapia and clarias in China and Vietnam, respectively); processors (artisanal drying) and distributors (national and international transport to bring the products to market). The inventories were based on field surveys and were modelled as presented in Table 2. 
Table 2. Life cycle inventories by the type of unit of production of the Malian fisheries value chain.

\begin{tabular}{|c|c|}
\hline Unit of Production (UP) Type & Life Cycle Inventory Items \\
\hline Fishing by fishing units & $\begin{array}{l}\text { Fishers were modelled as UP considering the canoe, equipment, fuel consumption, average } \\
\text { catches, including seasonal variations, and losses. Small pelagic fishing was based on the } \\
\text { processes developed for the Gambia. Farmed fish were modelled based on data from the } \\
\text { literature, tilapia using inventories of Chinese production [69] and clarias produced in } \\
\text { Vietnam based on the inventory in reference [70], considering the type of production } \\
\text { (intensive or integrated fish farming), consumption of feed, electricity, diesel and lime per t } \\
\text { of fish. }\end{array}$ \\
\hline Production of ice & $\begin{array}{l}\text { Modelled based on data collected in the field. The ice plants visited produced between } 30 \text { and } \\
60 \mathrm{t} \text { of ice per day in } 25-\mathrm{kg} \text { blocks, with an estimated average consumption of } 50 \mathrm{kWh} / \mathrm{t} \text { of ice. }\end{array}$ \\
\hline Fish processing & $\begin{array}{l}\text { Fish processing, both artisanal and industrial, was modelled in terms of fuel consumption } \\
\text { (liquid fuels and biomass), chemicals and packaging materials, product yields and water and } \\
\text { waste generation, as recommended in the literature }[41,59] .\end{array}$ \\
\hline Fish distribution & $\begin{array}{l}\text { Transport distances in Mali are significant. For the fish that remained on the fishing grounds, } \\
\text { only the use of the collection canoe was considered. To reach urban markets, fresh fish } \\
\text { travelled an average of } 540 \mathrm{~km} \text { calculated by weighting the distances to the main fishing areas } \\
\text { by the production volumes. Smoked fish travels } 635 \mathrm{~km} \text { (Mopti to Bamako). Frozen imported } \\
\text { marine fish arrives by truck from the main ports (Mauritania and Senegal, average distance } \\
1448 \mathrm{~km}) \text { and from Morocco and Namibia ( } 1371 \mathrm{~km}) \text {. Farmed fish is transported as } \\
\text { refrigerated cargo by freighter from Asia }(19,446 \mathrm{~km} \text { and } 16,800 \mathrm{~km} \text { from China and Vietnam, } \\
\text { respectively) to the port of Dakar and then by refrigerated truck to Bamako ( } 1200 \mathrm{~km}) \text {. }\end{array}$ \\
\hline
\end{tabular}

\subsubsection{Environmental Impact Assessment}

Results of environmental impacts are presented by the area of protection, followed by the contribution analysis per ton of product. Then, the single score $(\mathrm{Pt})$ and Cumulative Energy demand (CED) in MJ are shown. Detailed impact assessment results, including midpoints indicators, are presented in the Supplementary Materials.

\section{Absolute and Relative Environmental Impacts}

Impacts were calculated for three areas of protection: human health, ecosystems and resources (Figure 2). The impacts of both fisheries and processing activities, including the transport of fish products, predominantly affect AoP human health in both countries.

(a)

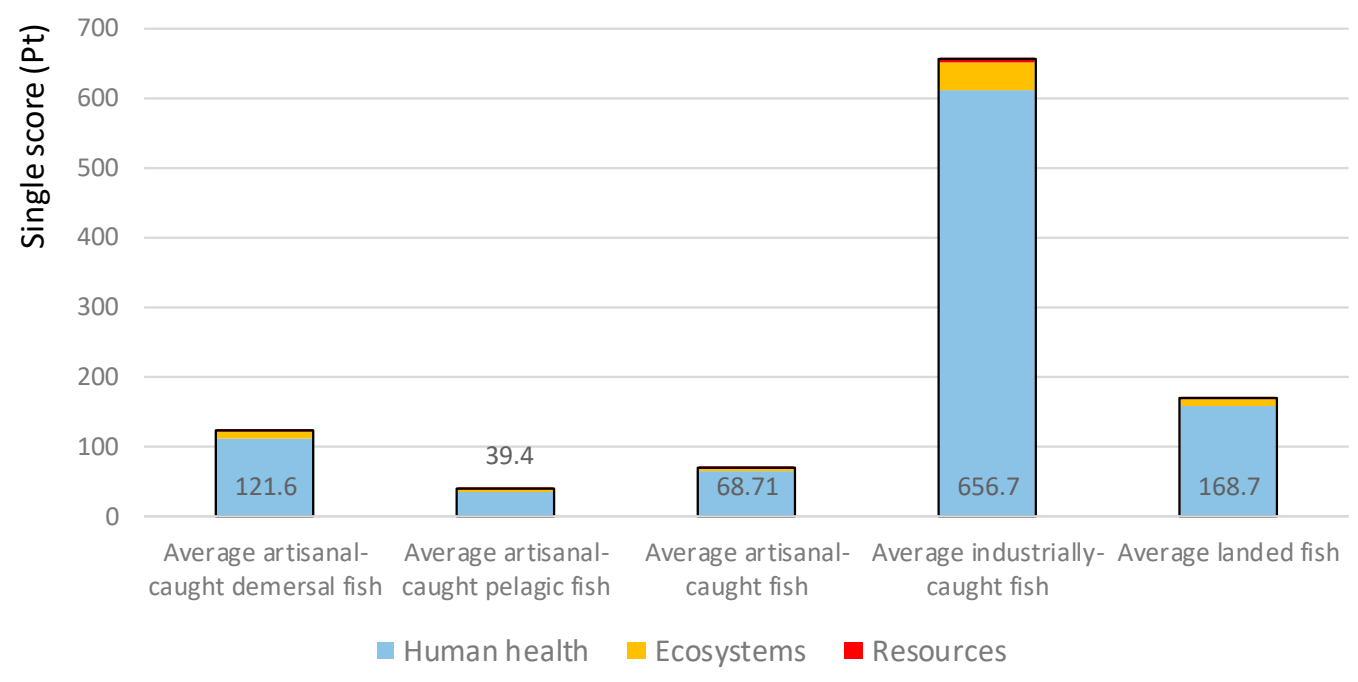

Figure 2. Cont. 
(b)

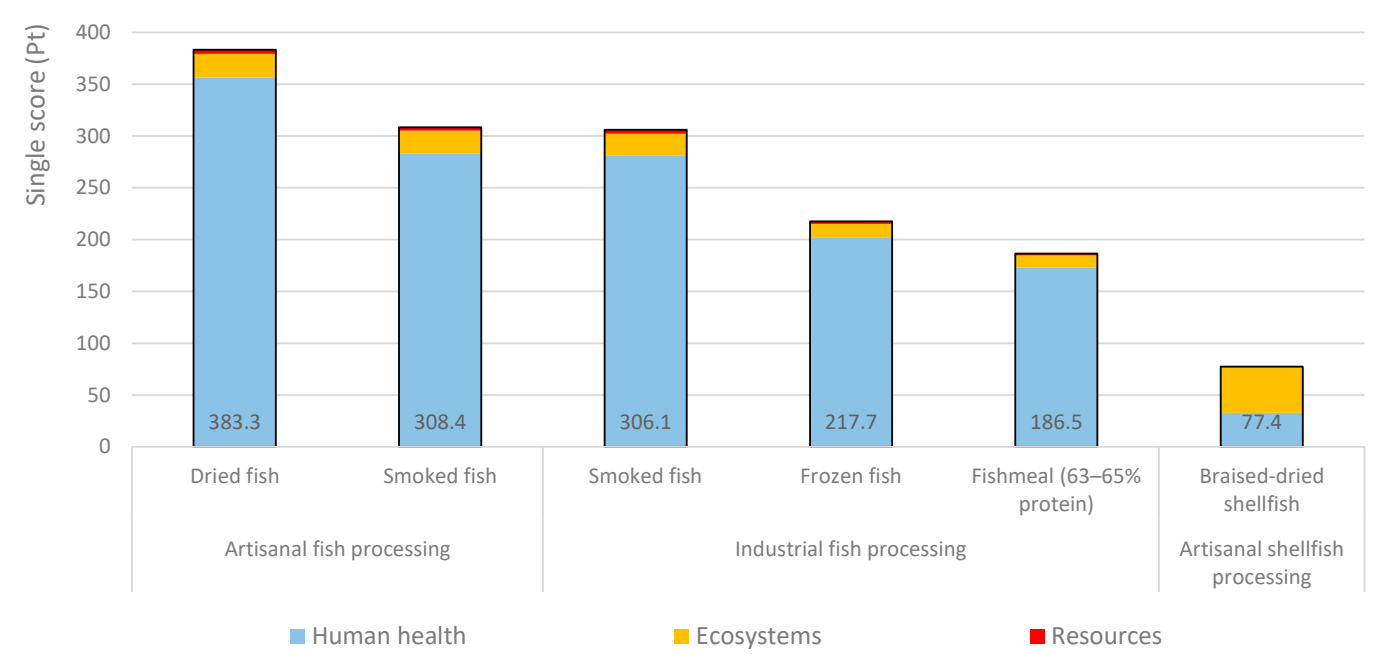

(c)

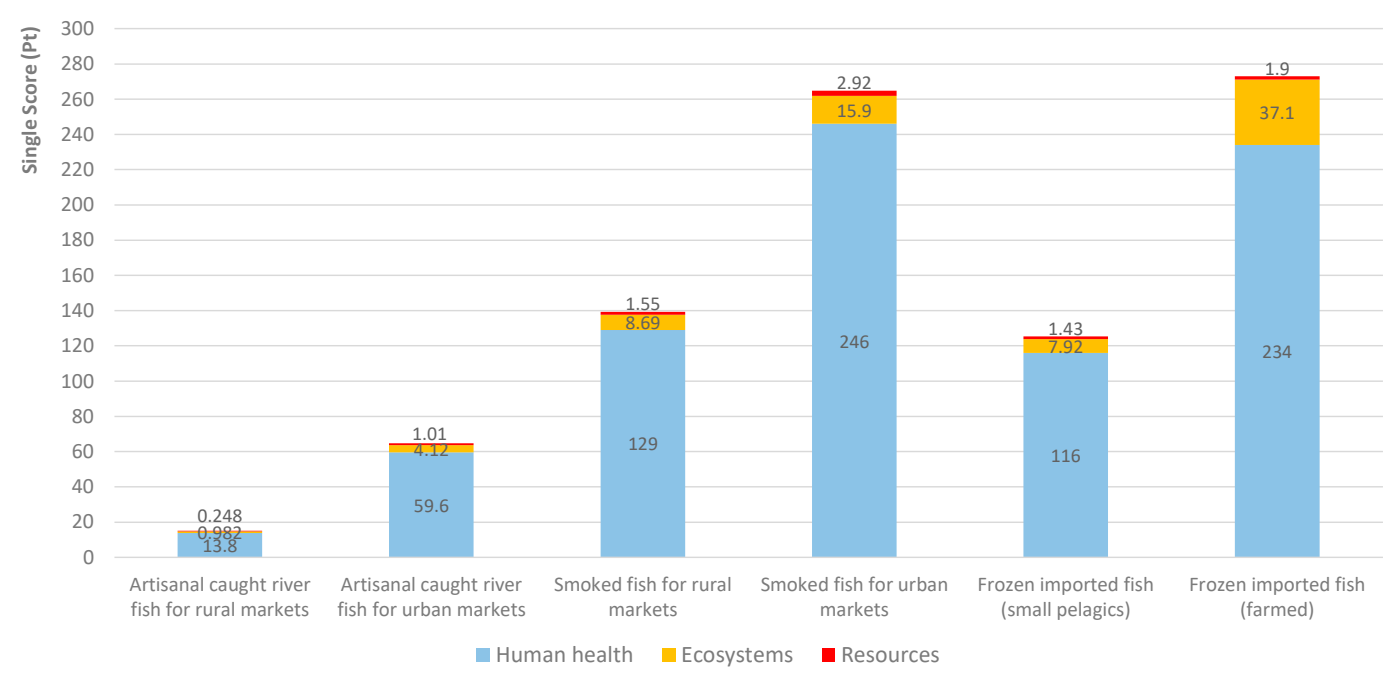

Figure 2. Endpoint environmental impacts per $t$ of product and per area of protection: (a) average fish captures in the Gambia, (b) processed products in the Gambia and (c) average fish products in Mali.

In the Gambia, impacts of the average fish captures from industrial fleets are higher than those of demersal artisanal fleets, disagreeing with the results from other studies [71], since, usually, industrial vessels benefit from economies of scale. Industrial fisheries, in particular, are very inefficient, with a large, normalised impact on human health. However, given the low percentage of industrial captures to the overall captures $(17 \%$ vs. $83 \%$ by artisanal fleets), the impact of the average captured $t$ of fish remains relatively low. The reasons of this specific dynamic in Gambian fisheries are multiple: the unusual shape of the Gambian Exclusive Economic Zone (EEZ) and the respective fishing zones for the artisanal and industrial fleets, the status of the targeted stocks limiting economies of scale and even the skipper effect limiting the performance of industrial vessels [48]. Moreover, the proxy Senegalese and Mauritanian data used to model industrial fisheries and fishmeal production may not be fully representative of the Gambian conditions.

The results of the fish-processed products in the Gambia (Figure 2b) showed that the fishmeal industry features lower impacts per $t$ of product than all other fish processing activities, including artisanal ones. This is, in part, due to the other processing industries consuming mainly demersal fish, which features even higher fishery impacts than the small pelagics consumed by the fishmeal industry. Moreover, fish processing features important losses (cleaning residues, etc.), while the fishmeal industry does not. 
In Mali, comparing all products (Figure 2c), imported fish and smoked fish in urban markets have the highest impacts. The uses of these products are rather different: smoked fish is consumed in small quantities as a spice, and its conservation lifetime is between 3 and 12 months. Frozen imported fish is sold in markets as a replacement of fresh fish, because of its competitive price and the packaging and transport conditions, which guarantee a much higher level of freshness than the current conditions in Mali local fish: outdated ice factories with a reduced supply in relation to demand coupled with inefficient storage conditions (old refrigerators and freezers out-of-order or otherwise non-operational). However, the potential environmental impacts are almost four times higher than local fish.

\section{Contribution Analyses}

The relative contribution of each element of the system to the estimated impacts is presented in a contribution analysis of the Gambian fish products (Figure 3). For most fishing activities, fuel consumption contributes to $>90 \%$ of impacts (Figure 3a). The impacts of fish processing are determined mainly by the impacts of the supplying fisheries, except for shellfish processing, for which the main driver for the impacts is the combustion of wood as fuel (Figure 3b).

(a)

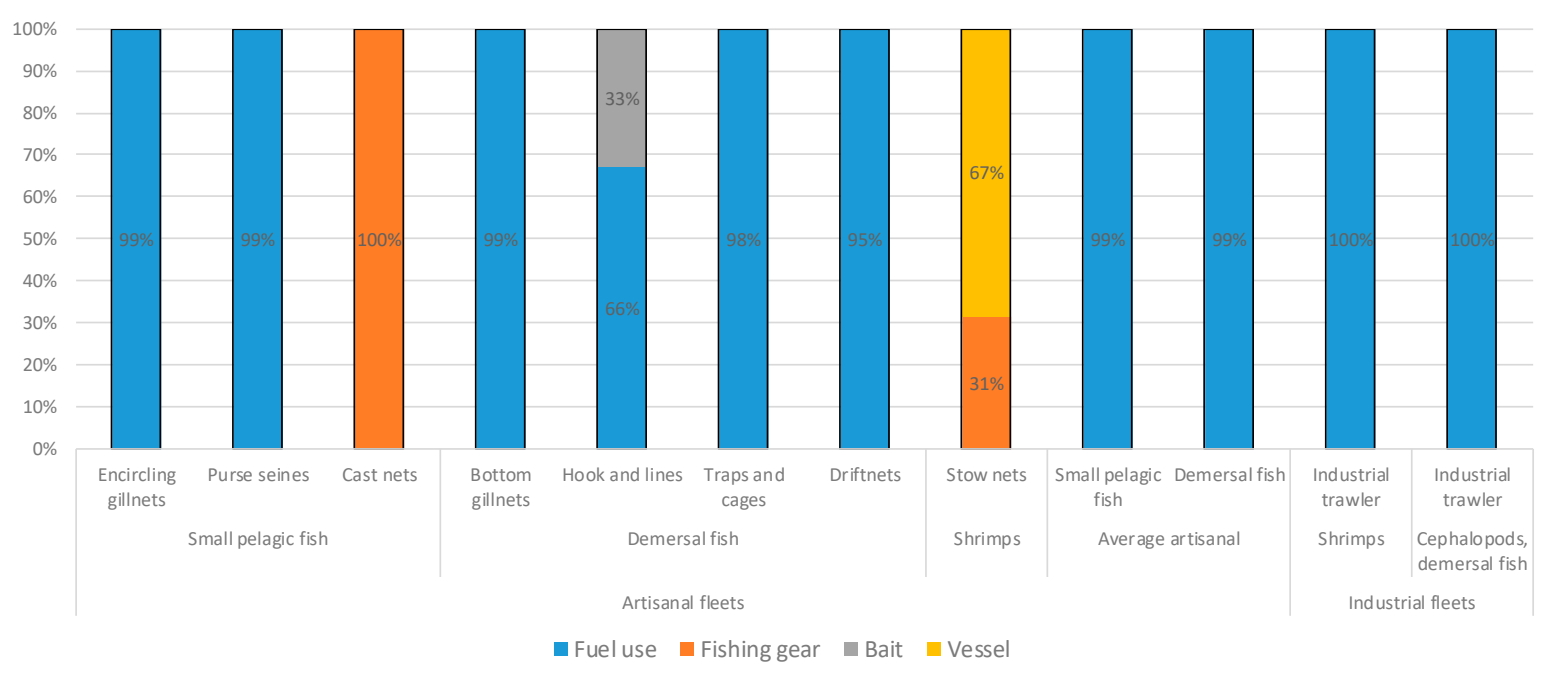

(b)

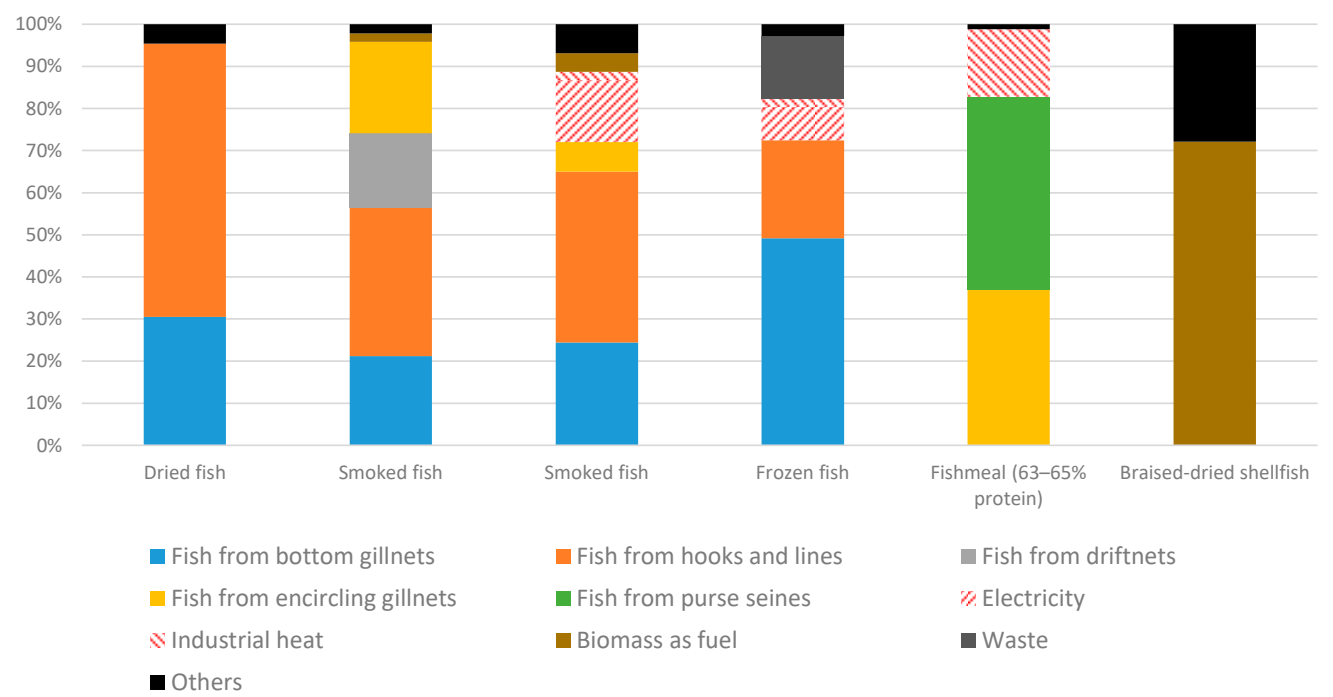

Figure 3. Contribution analysis of Gambian fish products per t of product and relative to the single scores of (a) fresh fish products and $(\mathbf{b})$ processed fish products. 
In Malian fisheries, as in the Gambia fisheries, fuel use is the main contributor to the estimated impacts when canoes are motorised (Figure $4 \mathrm{a}$ ). Fuel is the source of $67-98 \%$ of the potential impacts, depending on the impact category. The motorisation rate is rapidly increasing. For the analysis, data from field surveys were used. The average amount of fuel used was estimated according to the proportion of motorised canoes per type of fishing unit.

The canoe fleets used by part-time and full-time fishers feature the motorisation of $\sim 50 \%$ (one out of every two fishing units is motorised), while diversified fishers attain $10 \%$ and opportunistic fishers $0 \%$, as they tend to use shore gear. Fuel consumption was multiplied by the motorisation rate, because the catch levels vary little with or without motorisation, as the limiting factor seems to be the equipment and the potential of the fishing areas. It was difficult to estimate a motorisation rate representative of all fishing areas, because according to the interviews, between $10 \%$ and $100 \%$ of canoes are motorised, whereas, according to the West African Economic and Monetary Union [12], only 10\% of fishing units are motorised. The results by motorised/non-motorised canoes (Figure $4 \mathrm{~b}$ ) show the importance of this factor on the potential environmental impacts. Fishing gear is the following contributor; most nets and fishing tools are imported and made of nylon or other synthetic materials, including lead from recycled car batteries. In the last years, it has replaced traditional handmade gears, the materials of which were biodegradable. Even if most of materials are recycled at the end (fishing nets are woven into ropes), this point represents a point of attention.

(a)

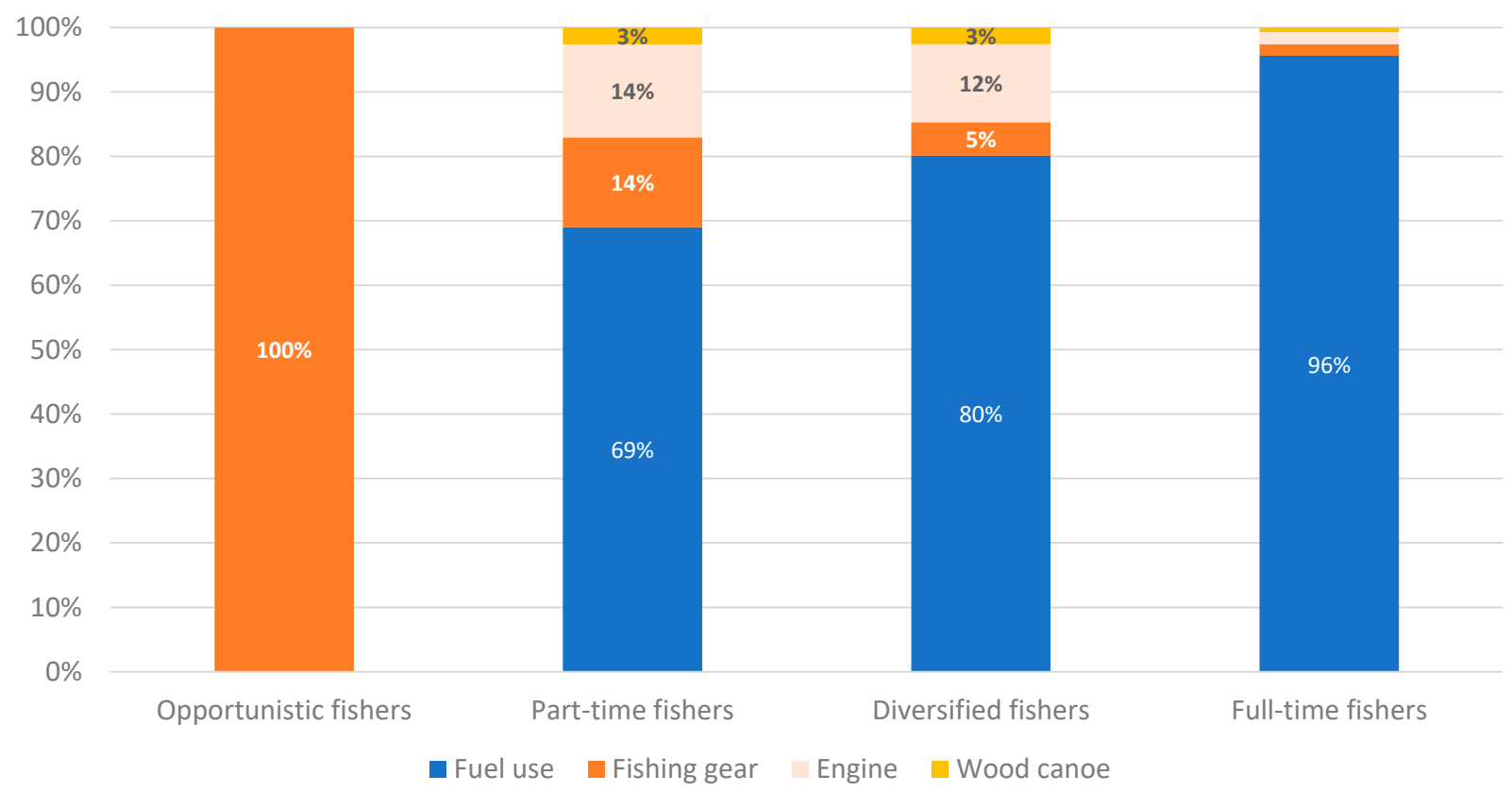

Figure 4. Cont. 
(b)

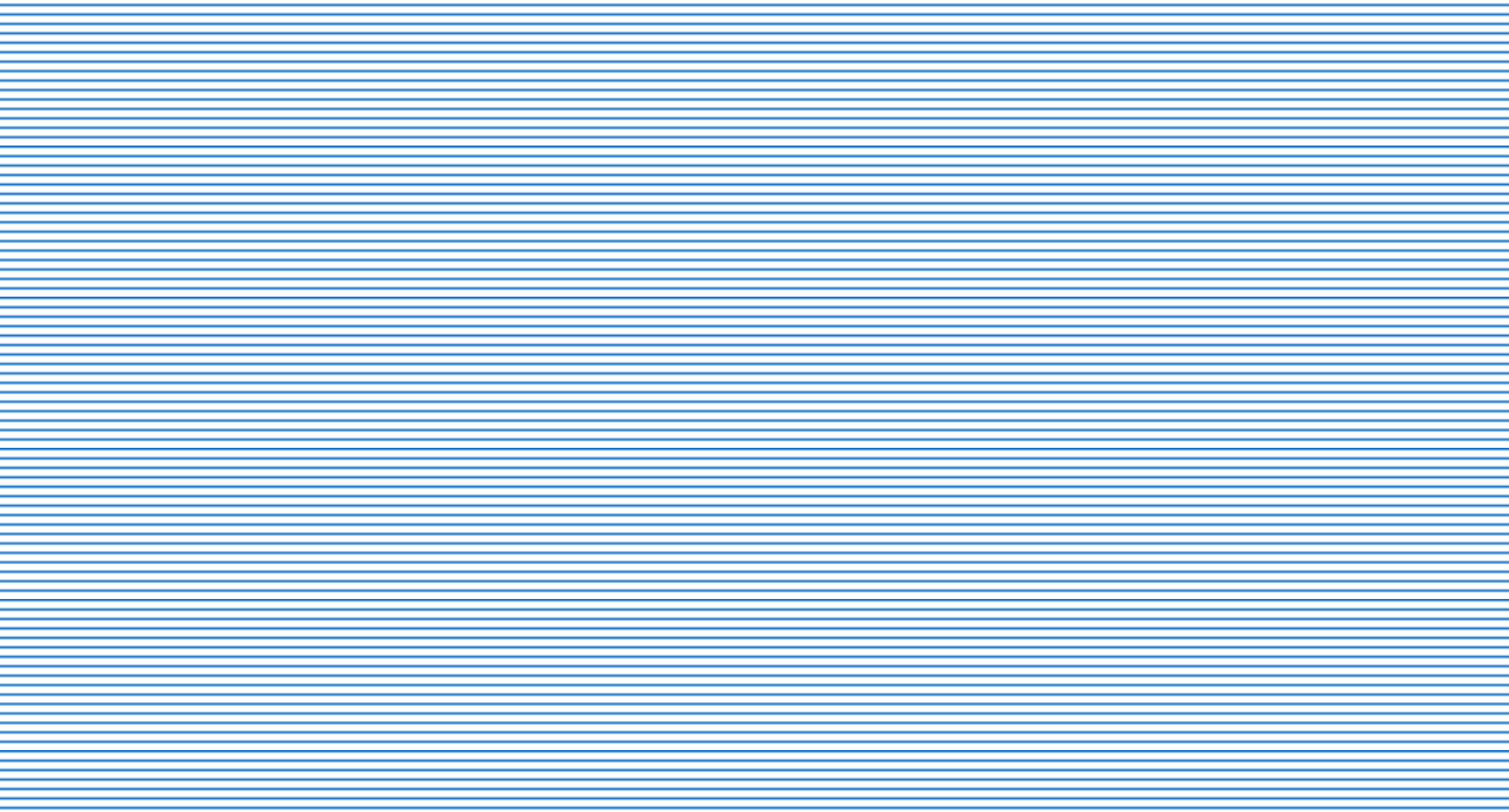

Figure 4. Contribution analysis of Malian fresh fish products per type of fisher, per $t$ of product, relative to the single score, of those (a) non-segregated by motorisation and (b) segregated by motorisation.

The contribution analysis by type of product available on the Malian market (Figure 5) shows that the fishing activity is the main contributor to impacts, even for smoked fish, with processing having little impact in comparison. For imported frozen fish, the production of fish and the concentrate feed used are the most important in the case of fish from fish farms, followed by transport. For imported frozen small pelagic fish, it is the fishing and freezing stages that have the greatest impacts.

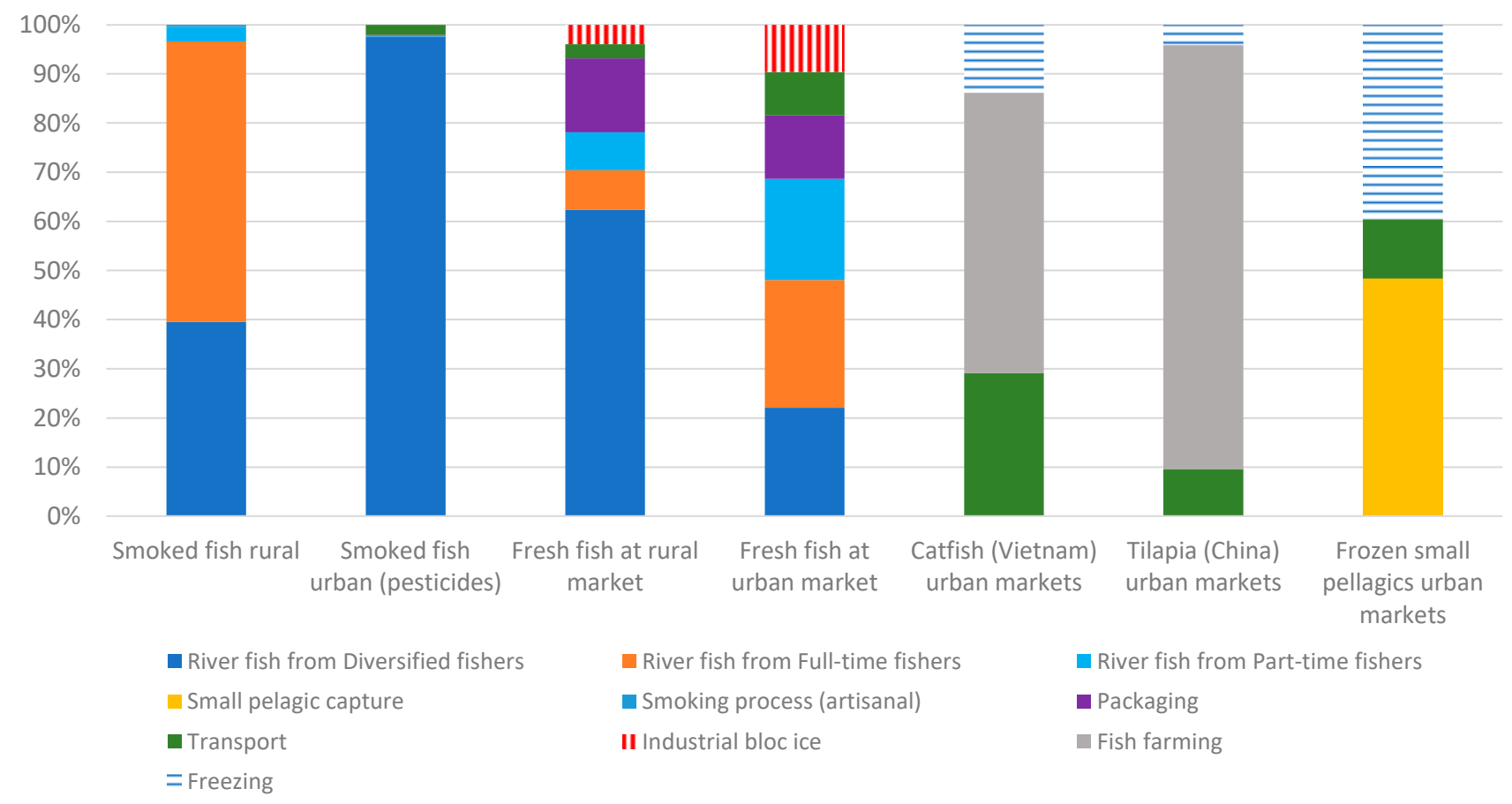

Figure 5. Contribution analysis of Malian transported fresh fish, processed fish products and imported fish products per $t$ of product and relative to a single score. 
The transport of fish products in the Gambia has a relatively minor contribution to the overall impacts, even including the production of ice used in the transport of fresh fish (Figure S2 in the Supplementary Materials), probably due to the relatively small road distances to be covered. The actual impacts are probable higher, due to the conditions of Gambian roads and vehicles, many of which probably do not fulfil the European emission standard "Euro 3" specifications, as is common in Africa [72,73].

In Mali, on the other hand, as distances are more important, the impact of fresh fish transportation is very considerable, representing up to 3.6 times the impact of landed fish (i.e., a single score of $64.7 \mathrm{Pt}$ for fresh fish transported to urban markets vs. $18.0 \mathrm{Pt}$ for the average $t$ of landed fish, the latter dominated by landings by diversified fishers).

\section{Single Score and Cumulative Energy Demand}

A comparison of the environmental impacts expressed as a single score for all Gambian and Malian fresh and processed fish products are presented, respectively, in Table 3 with the estimation of the additional indicator Cumulative Energy Demand, which was used to calculate the energy return on investments and protein-per-impact, two eco-efficiency indicators.

Table 3. Single score and cumulative energy demand (CED) of Gambian and Malian fish products per t of product.

\begin{tabular}{|c|c|c|c|c|}
\hline Value Chain & Product & Production Units & $\begin{array}{l}\text { Single Score } \\
(\mathbf{P t})\end{array}$ & CED (MJ) \\
\hline \multirow{12}{*}{$\begin{array}{l}\text { The Gambia } \\
\text { (landings) }\end{array}$} & \multirow{3}{*}{$\begin{array}{l}\text { Small pelagic fish, landed whole, } \\
\text { fresh (artisanal) }\end{array}$} & Encircling gillnets & 45.7 & 7437 \\
\hline & & Purse seines & 30.4 & 4946 \\
\hline & & Cast nets & 0.03 & 11.7 \\
\hline & \multirow{5}{*}{$\begin{array}{l}\text { Demersal fish, landed whole, fresh } \\
\text { (artisanal) }\end{array}$} & Bottom gillnets & 114.3 & 18,578 \\
\hline & & Driftnets & 190.8 & 34,871 \\
\hline & & Long lines & 190.0 & 31,190 \\
\hline & & Traps and cages (cephalopods) & 13.7 & 2407 \\
\hline & & Stow nets (shrimp) & 0.9 & 1289 \\
\hline & \multirow{2}{*}{ Average artisanal-caught landed fish } & Pelagic fish & 39.4 & 6415 \\
\hline & & Demersal fish & 121.6 & 20,353 \\
\hline & \multirow{2}{*}{$\begin{array}{l}\text { Demersal fish, landed whole, frozen } \\
\text { (industrial) }\end{array}$} & Trawlers (shrimp) & 1047.6 & 165,014 \\
\hline & & Trawlers (cephalopods and fish) & 632.3 & 99,596 \\
\hline \multirow{5}{*}{ Mali (landings) } & \multirow{4}{*}{$\begin{array}{l}\text { River fish, landed whole, fresh } \\
\text { (artisanal) }\end{array}$} & Opportunistic fishers & 3.0 & 1568 \\
\hline & & Part-time fishers & 45.8 & 11,813 \\
\hline & & Diversified fishers & 28.6 & 5957 \\
\hline & & Full-time fishers & 80.1 & 13,300 \\
\hline & Average landed fish & Artisanal-caught river fish & 18.0 & 4510 \\
\hline \multirow{6}{*}{$\begin{array}{l}\text { The Gambia } \\
\text { (processing) }\end{array}$} & \multirow{3}{*}{ Artisanal processed fish } & Dried fish & 383.3 & 61,418 \\
\hline & & Smoked fish & 308.4 & 68,783 \\
\hline & & Shellfish collecting and braising & 77.4 & 216,061 \\
\hline & \multirow{3}{*}{ Industrially processed fish } & Smoked fish & 306.1 & 72,927 \\
\hline & & Frozen fish & 217.7 & 39,184 \\
\hline & & Fishmeal, $63-65 \%$ protein & 186.5 & 32,457 \\
\hline Mali (processing) & Artisanal processed fish & $\begin{array}{l}\text { Smoked Tigerfish } \\
\text { (pesticides-treated) }\end{array}$ & 265.1 & 44,104 \\
\hline \multirow{3}{*}{ Mali (imports) } & \multirow{2}{*}{$\begin{array}{l}\text { From extensive pond aquaculture, } \\
\text { whole, frozen }\end{array}$} & Tilapia (China) & 370.0 & 77,075 \\
\hline & & Catfish (Vietnam) & 73.4 & 16,651 \\
\hline & $\begin{array}{c}\text { From artisanal fisheries, whole, } \\
\text { frozen }\end{array}$ & Small pelagic fish (West Africa) & 217.7 & 39,181 \\
\hline
\end{tabular}


In the Gambia, industrial fleets had the highest values for the CED indicator and for processed products was shellfish collecting and braising, while the potential estimated impacts by the LCA were the lowest. In Mali, the highest values for CED were obtained by frozen imported tilapia, where an important amount of energy was needed to produce a concentrated feed. These results confirmed that the environmental impacts of the whole value chain are driven by inefficient fuel (liquid fossil fuels, wood and other biomass) consumption.

\subsection{Eco-Efficiency: Fuel Use Intensity, Energy Return on Investment and Protein-Per-Impact \\ 3.2.1. Fuel Use Intensity}

Eco-efficiency indicators were computed for all landed fish and elaborated fish products from the two value chains. In the Gambia, the weighted average of artisanal pelagic FUI was $150 \mathrm{~L} / \mathrm{t}$ and that of artisanal demersal was $401 \mathrm{~L} / \mathrm{t}$. The weighted average of industrial demersal FUI was $2055 \mathrm{~L} / \mathrm{t}$. The global mean FUI for small pelagic fish, in contrast, has been estimated at $42 \mathrm{~L} / \mathrm{t}$ and that of demersal fish and cephalopods at 539 and $613 \mathrm{~L} / \mathrm{t}$, respectively [74]. If the contribution to total captures by industrial fleets is expected to increase, attention should thus be paid to improving their fuel use efficiency (e.g., reducing their FUI) and their potential contribution to stocks depletion.

For processed products in the Gambia, the environmental performance of fishmeal production is not driven by fuel consumption, as happens, for instance, for the Peruvian fishmeal industry [62], but by the FUI of the supplying fisheries. This can be explained by the important differences in FUI providing the fishmeal industry around the world: Peruvian purse seiners consume $<20 \mathrm{~L}$ of fuel per $t$ fish [58], while Gambian purse seiners consume $104 \mathrm{~L} / \mathrm{t}$ and encircling gillnets $163 \mathrm{~L} / \mathrm{t}$. As a reference, mean African encircling gillnets feature a FUI of $31 \mathrm{~L} / \mathrm{t}$ [75]. The fuel consumption of shrimp-targeting vessels, both industrial and artisanal, resembles those of the respective Senegalese fleets, as described in reference [61].

Fishmeal production, in particular, compares negatively with Peruvian and global fishmeal production, mainly due to the relatively higher impacts of raw material provision (Figure S3 in the Supplementary Materials) and marginally to different technology levels. Peru, for instance, increasingly uses state-of-the-art indirect drying fuelled by natural gas [62] instead of the direct drying fuelled by heavy fuel most commonly used in West Africa (pers. comm. with various experts in the Mauritanian and West African fishmeal industry).

In Mali, the FUI of full-time fishers, diversified fishers and part-time fishers using motorised canoes reaches, respectively, $234 \mathrm{~L} / \mathrm{t}, 70 \mathrm{~L} / \mathrm{t}$ and $97 \mathrm{~L} / \mathrm{t}$. For processed products, the fuel consumption is the main driver of impacts, but it remains rather low compared to the FUI for artisanal inland fisheries in developing countries, which has been estimated at $\sim 1200 \mathrm{~L} / \mathrm{t}$ [76].

\subsubsection{Energy Return on Investment and Protein-Per-Impact}

EROI and PPI are two eco-efficiency indicators that also give information about the food security of the value chains-in particular, for an important source of protein as fish. The composition data required to compute EROI and PPI is summarised in Table 4, and the computed indicators are presented in Figure 6. As expected, the less energyintensive fisheries, as indicated by a lower FUI, feature higher (i.e., better) EROI. These fishing units include cast nets and stow nets in the Gambia and opportunistic fishers in Mali (Figure 6a). Moreover, as environmental impacts are generally correlated with FUI, higher (i.e., better) PPI are associated with the same types of fishing units. Regarding processed fish products, Gambian fishmeal production benefits from economies of scale, as reflected in both EROI and PPI (provided that the protein in fishmeal is not for direct human consumption and requires cycling through farmed fish). Smoked Malian products feature higher EROI and PPI values than Gambian ones, probably due to a combination of lower FUI of the providing fishing units and the use in Mali of cow dung to complement 
wood for fish smoking (Figure 6b). Gambian-processed shellfish features rather high PPI, due to relatively lower impacts associated with collection and braising. The EROI of fish products imported to Mali are low due to the energy expenditures of the refrigerated transport and energy needed to produce a concentrated feed. In contrast, for instance, Peruvian-cultured tilapia features EROI values of 4.3 ( 0.03 for frozen tilapia imported from China to Mali) [22].

Table 4. Fat, protein, gross energy content (GEC) and edible yield of the main species and fish products of the Gambia and Mali.

\begin{tabular}{|c|c|c|c|c|}
\hline Gambian Products & Lipid Content (\%) & Protein Content $(\%)$ & GEC (MJ/kg) * & Edible Yield (\%) \\
\hline Bonga shad & 8.7 & 18.5 & 7.6 & 62 \\
\hline Flat sardinella & 4.5 & 22.7 & 7.0 & 65 \\
\hline Round sardinella & 4.5 & 21.0 & 6.6 & 59 \\
\hline West African ladyfish & 5.3 & 23.0 & 7.4 & 57 \\
\hline Cunene horse mackerel & 5.8 & 19.7 & 6.8 & 57 \\
\hline Common octopus & 1.3 & 17.3 & 4.5 & 68 \\
\hline Sole fish/Tonguefish & 1.4 & 19.8 & 5.1 & 68 \\
\hline Cuttlefish & 1.4 & 18.0 & 4.7 & 63 \\
\hline Mullets & 0.8 & 20.0 & 4.9 & 50 \\
\hline Pink shrimp & 1.3 & 20.4 & 5.2 & 57 \\
\hline Dentex & 2.5 & 19.9 & 5.5 & 52 \\
\hline Catfishes & 1.9 & 21.3 & 5.6 & 52 \\
\hline White grouper & 1.0 & 19.4 & 4.9 & 60 \\
\hline Sharks, skates, rays & 4.5 & 21.0 & 6.6 & 70 \\
\hline Hairtails, Cutlassfishes nei & 4.1 & 18.8 & 5.9 & 59 \\
\hline Dried fish & 8.4 & 61.7 & 17.5 & 70 \\
\hline Smoked fish & 7.4 & 33.9 & 10.7 & 70 \\
\hline Braised shellfish & 1.5 & 18.0 & 4.7 & 100 \\
\hline Frozen fish & 2.7 & 19.4 & 5.5 & 63 \\
\hline Malian Products & Lipid Content (\%) & Protein Content (\%) & $\operatorname{GEC}(\mathrm{MJ} / \mathrm{kg}) *$ & Edible Yield (\%) \\
\hline Bayad & 1.2 & 17.1 & 4.4 & 60 \\
\hline African catfish & 5.7 & 16.3 & 6.0 & 52 \\
\hline Freshwater catfish & 5.7 & 16.3 & 6.0 & 52 \\
\hline African carp & 0.6 & 15.7 & 3.8 & 54 \\
\hline Nile perch (Captain) & 2.0 & 19.9 & 5.4 & 61 \\
\hline Tilapias & 2.7 & 18.8 & 5.4 & 65 \\
\hline Mango tilapia & 5.1 & 22.4 & 7.1 & 37 \\
\hline Smoked Tigerfish & 6.2 & 73.3 & 19.3 & 70 \\
\hline
\end{tabular}

* Gross energy content (GEC) was computed from the lipid and protein contents following the energy contents of said components and equations presented in the FAO documents $[53,54]$. The lipid and protein contents and edible yields were retrieved from several FAO sources [54-57].

\subsection{Sensitivity and Variability}

In the LCA and impact assessment in general, the identification of sources of uncertainty are an important step to validate the results. In artisanal fisheries, the FUI (which depends on both the average landings per vessel and its associated fuel consumption) is the main driver of uncertainty. In artisanal fish and shellfish processing, their processed volumes, yields, losses and fuel consumption are a key source of uncertainty, as actors seldom keep records, and thus, all data were obtained from recalls. Regarding industrial fisheries and fish processing, their historical and detailed data is not easily accessible, as the companies tend to be very secretive about it. 
(a)

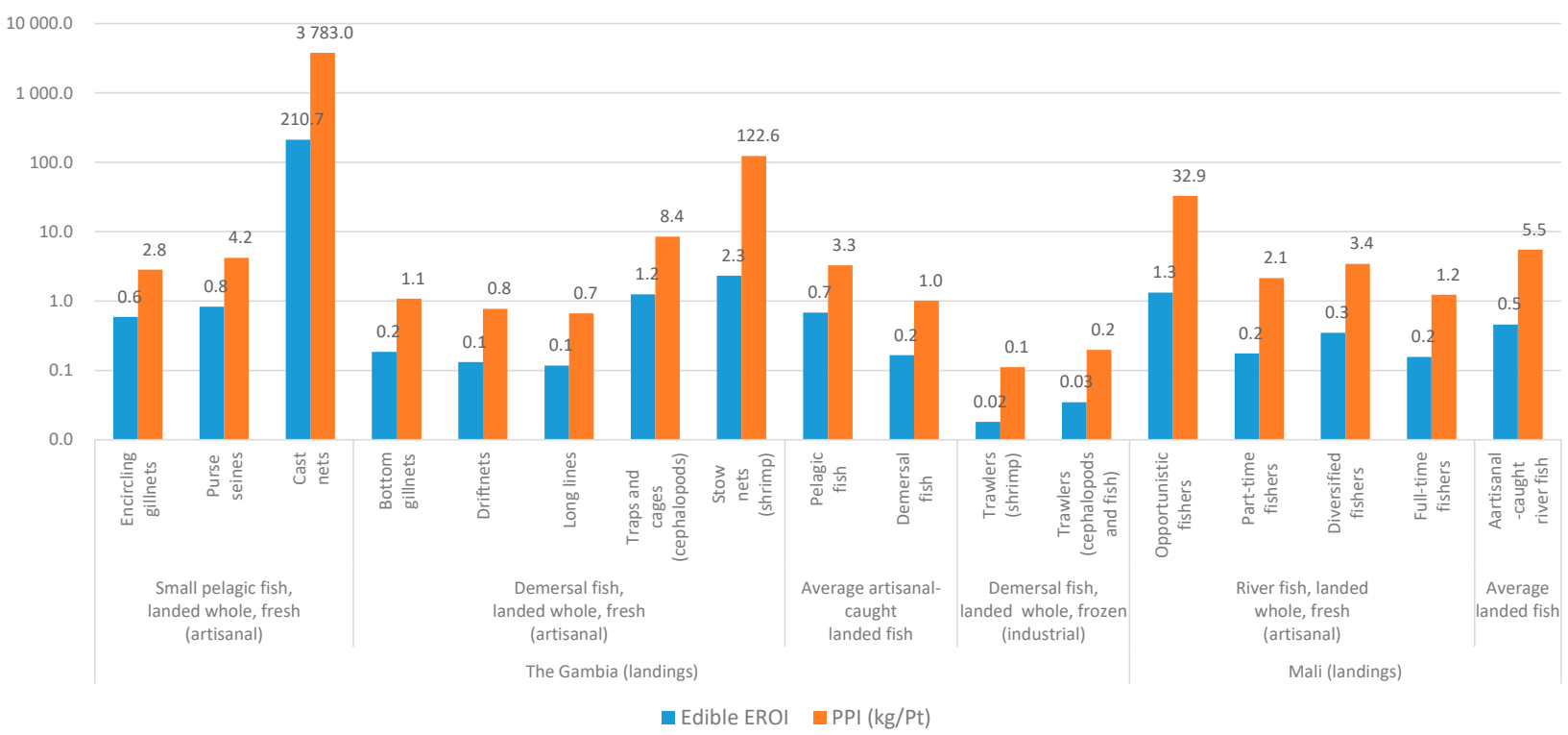

(b)

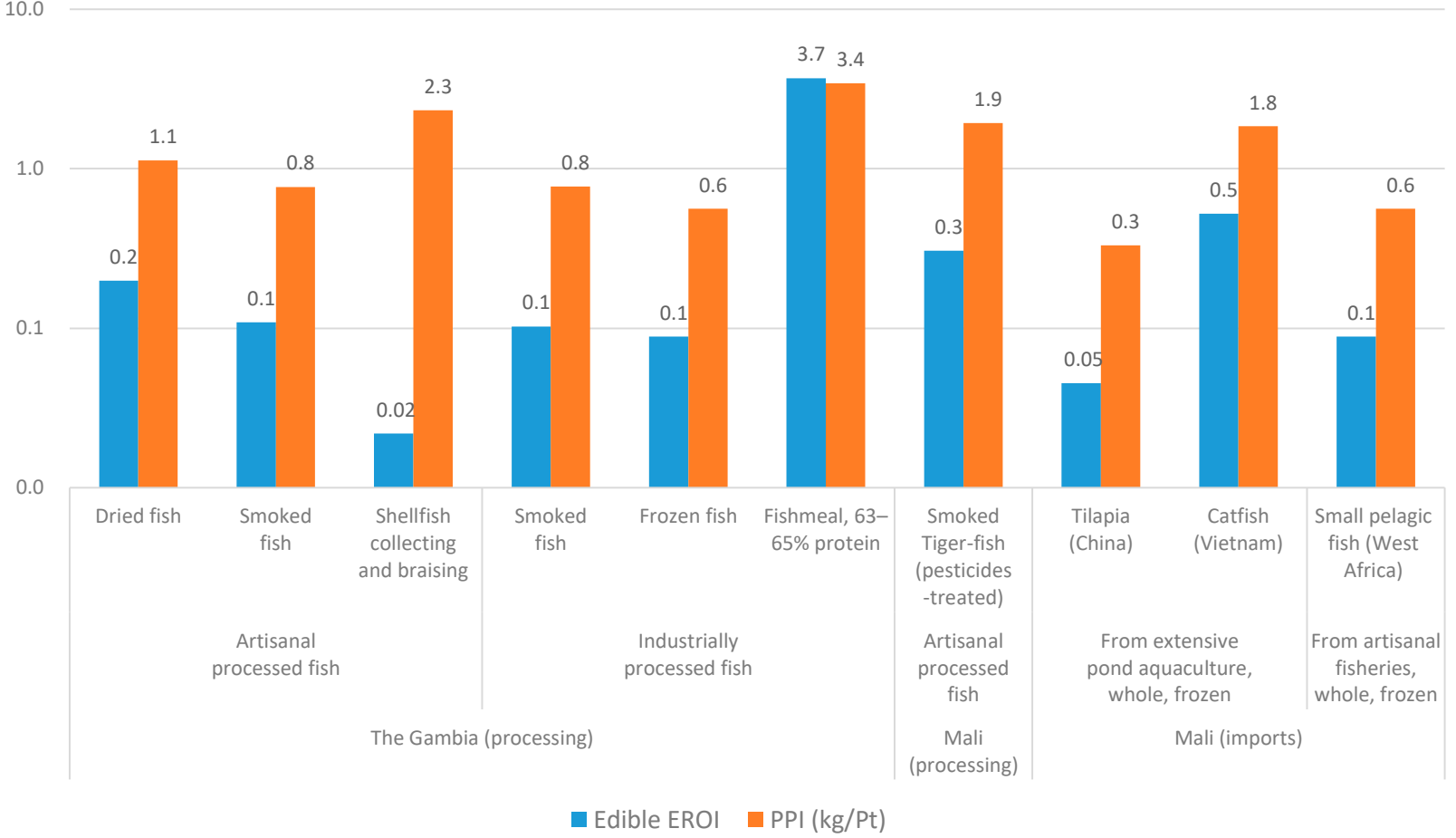

Figure 6. Edible energy return on the investment (EROI) and protein-per-impact (PPI) of Gambian and Malian fish products: (a) fresh fish and (b) processed fish.

A large variability in fishery performances may be assumed, due to the seasonal and interannual dynamics of the targeted stocks, as well as the variations in fishing skills (including the so-called skipper effect [48], which influences the FUI and, thus, fuel use efficiency). These fisheries factors also affect the processing industries provided by fisheries.

\section{Discussion: Priorities for Improvement}

The value chains mapping presented in reference [36] already suggested several improvement directions, but the environmental analysis presented here allows to prioritise them from an environmental and eco-efficiency point of view. Overall, each function delivered by sub-chains in the two value chains features areas for improvement, particularly 
regarding fuel consumption for fishing and infrastructure for processing. Support and development programmes can help to reduce environmental and human health impacts. Liquid and solid fuels, in particular, are known to have a direct impact on human health via the release of particulates and other contaminants though combustion [77]. The assessments conducted excluded important sources of impact on oceans and other water bodies associated with fisheries, such as plastics and microplastics (from waste disposal at sea or gear loss, among other sources [78]) or bilge waters disposed of in the ocean, for which characterisation factors are generally lacking (until recently for marine litter [79]).

The improvements of landing and processing infrastructures, as well as the introduction of better fish processing methods, are clearly a priority from an eco-efficiency perspective. In both countries, inefficient fuel (liquid fossil fuels, wood and other biomass) consumption is the main driver of environmental impacts of the fishery-based value chains. As both countries exploit rather abundant stocks (more seasonally distributed in Mali), mainly by passive fishing gear, such efficiency gains in fishing units should come from improved/well-maintained engines and/or skipper training in fuel-saving strategies. For artisanal fish processing, improved infrastructure such as efficient smoking ovens [80] would reduce the consumption of biomass and reduce spoilage. Moreover, as widely discussed in the literature, technical and business training (e.g., record-keeping) is lacking among West African artisanal actors [81-84].

Globally, wild caught fish yields have stagnated, while the fishing effort has increased [85]. It has been reported that the CPUE of West African artisanal fisheries has been steadily decreasing (by one-third to date) since the 1950s and that artisanal CPUE is 11-fold less than industrial CPUE [86]. That means that (i) the fishing effort (i.e., time and fuel) has increased dramatically while catches have not; in other words, the efficiency has diminished, and (ii) that artisanal fisheries are one order of magnitude less efficient than industrial ones. This second statement is in contrast with the results presented. The low eco-efficiency of the industrial Gambian fishing units compared to other industrial fleets showed the need to assess not only the stocks and catch effort but, also, to include other environmental indicators from a LCA perspective, since industrial fishing has a spatial extent more than four times that of agriculture ( $>55 \%$ of the ocean area) [87].

Artisanal continental fisheries feature very few inputs, coupled with a high recycling rate of fishing materials and equipment. Despite a low level of investment, artisanal fishing in Mali contributes 7\% to agricultural GDP and ensures food security and income for an increasing number of families. Nonetheless, the rapid trend towards the motorisation of canoes may increase environmental damage unless the same level of fuel intensity is maintained. The role of artisanal fishing must be recognised, and some authors call for prioritising this sub-sector [27] and its importance not only for subsistence but, also, in the lives of fishers in general [6] while recognising that the lack of management, regulation and monitoring are needed to avoid overexploitation.

Gambian fishing units are specialised according to the target species, and catches are mostly sold rather than consumed by the fishers' families. In Mali, as in most of inland African countries, fishing is rather artisanal, and the catches are destined for local consumption. Fishers have developed different strategies with a wide range of simple and artisanal equipment to adapt to the variability of the Niger River changes. As in other regions, overexploitation, illegal and unreported activities, weak and uncoordinated institutions, lack of reforms and the untapped potential of small-scale fisheries are still challenges to overcome $[7,9]$. This sector features large gaps in the available data. For instance, fisheries and aquaculture statistics, especially those representing African smallscale activities, continue to lack in quality, as recently highlighted by FAO [88].

Fisheries management based exclusively in stock assessment and monitoring fishing effort disregards the behaviour of industrial fishing vessels that seems to be insensitive to the energy or seasonal costs but, rather, shaped by politics and culture [87] and, in the case of West Africa, the great influence of the environment over fish stocks, which are climate-driven $[6,89]$ and sensitive to hydrological resources $[90,91]$. 
The import of frozen fish (wild caught small pelagics and cultured freshwater fish) is rapidly gaining importance in Mali and other landlocked African countries such as Zambia [92,93]. There is an ongoing trend and discussion about the imports of cheap Asian fish in Africa [93-96]. A recent study [37] showed the social, economic and environmental impacts of imported fish through the value chain.

To respond to the growing demand for fish, aquaculture is a potential pathway. For instance, FAO preconizes the further development of aquaculture in Africa as a priority [2]. The results presented here showed higher impacts of fish farming compared to local captures; thus, it seems that promoting intensive fish farming based on concentrated feed and intensive energy use (fuel and energy) will probably increase the environmental impacts of fisheries. For the sustainable development of aquaculture in Africa, a number of infrastructure, know-how and financial and technological challenges would need to be overcome [92,97-99].

\section{Conclusions}

The efficiency of Gambian and Malian fisheries, as well as the eco-efficiency of said fisheries and fish processing, were quantified by means of LCA-derived indicators. It was found that both metrics are relatively lower than the equivalent global processes and products, except for Malian inland fisheries. The main reasons for such performances include the type of fishery organisation and governance prevailing in these countries, which determines a continuous race for poorly regulated common-access resources. Moreover, migratory and/or high mobility fishing strategies increase fuel consumption. Improvements in the infrastructure and energy efficiency of fishing and processing units would likely contribute to improving the eco-efficiency of the fisheries-based value chain in both countries. Post-harvest losses, which directly impact food security, would be reduced with enhanced infrastructure and processing methods. The availability of data on these sectors is rather limited, and the activities are poorly monitored. Beyond the enhancement of the infrastructure, increased access to technical support, as well as the monitoring of indicators of pressure on resources, would allow for better knowledge and more effective support leading to a revitalisation of these value chains, coupled with improved environmental performances.

Supplementary Materials: The following are available online at https: / www.mdpi.com/article / 10.3390 /foods10071620/s1, Figure S1: Mapping of the main actors and major material and economic flows in the value chain (detailed). Figure S2: Impacts of transporting $1 \mathrm{tkm}$ of product (log scale), under different vehicle standards, and impacts of producing $1 \mathrm{t}$ of ice in The Gambia. Figure S3. Comparison of West African and global fishmeal production, per $t$ of product and per area of protection. Table S1: Abridged life cycle inventories of sub-fleets (units of production for fisheries) in The Gambia (average 2014-2018). Table S2: Abridged life cycle inventories of processing facilities (units of production for processing) in The Gambia (average 2014-2018). Table S3: LCIA of Gambian fisheries (ReCiPe 2016 Endpoint (H) V1.03/World (2010) H/A (per Area of Protection) and Cumulative Energy Demand v1.11) including energy (Gross Energy Content) and protein in whole fish. Table S4: LCIA of Gambian fish processing (ReCiPe 2016 Endpoint (H) V1.03/World (2010) H/A (per Area of Protection) and Cumulative Energy Demand v1.11) including energy (Gross Energy Content) and protein in whole fish. Table S5: Modelled Malian fishing products volume per year. Table S6: Main characteristics of artisanal fishing units in Mali. Table S7: Abridged life cycle inventories of canoes (per fishing units) in Mali (average 2017-2019). Table S8: Abridged life cycle inventories of fishing gear (per fishing units) in Mali (average 2017-2019). Table S9: Abridged life cycle inventories of transport for imported gear. Table S10: Abridged life cycle inventories of transport for imported gear. Table S11: Abridged life cycle inventories of collection operations of Malian artisanal fresh fish. Table S12: Abridged life cycle inventories of transport operations of Malian fish products. Table S13: Abridged life cycle inventories of transport operations of imported frozen fish (small pelagics). Table S14: Abridged life cycle inventories of transport operations of imported frozen fish (fish farming). Table S15: LCIA of Malian fisheries, imported fish (small pelagics and fish farming) (ReCiPe 2016 Endpoint (H) V1.03/World (2010) H/A (per Area of Protection) and 
Cumulative Energy Demand v1.11). Table S16: LCIA of Malian artisanal fisheries products and imported fish products (ReCiPe 2016 Endpoint (H) V1.03/World (2010) H/A (per Area of Protection) and Cumulative Energy Demand v1.11.

Author Contributions: Both authors contributed to the conceptualisation, data collection, data analysis and writing. A.A. was in charge of the environmental analysis of the Gambian value chain, while I.A.-A. studied the Mali case. Both authors have read and agreed to the published version of the manuscript.

Funding: The authors were founded by the VCA4D—Value Chain Analysis for Development 20162022 programme (https: / / europa.eu/capacity4dev/value-chain-analysis-for-development-vca4d-), through grant agreement 2016/375-804.

Institutional Review Board Statement: Not applicable.

Informed Consent Statement: Not applicable.

Data Availability Statement: Raw primary data is not available due to confidentiality issues. All treated and anonymised data is available from the Supplementary Materials.

Acknowledgments: The authors acknowledge the contribution of various institutions and individuals to this work, namely theVCA4D team members involved in the Gambia-Moustapha Dème (ISRA), Adama Mbaye (ISRA) and Joseph Ndenn-and Mali-Ludovic Andres (IRSTOM), Marc Oswald (IRSTOM), Gian Nicolay (FiBL) and Henri Zerbo-projects; the project management unit in Brussels; the European Delegation in the Gambia and Mali and the national stakeholders and institutions who kindly gave us their time and provided data.

Conflicts of Interest: The authors declare no conflict of interest.

\section{References}

1. Godfray, H.C.J.; Beddington, J.R.; Crute, I.R.; Haddad, L.; Lawrence, D.; Muir, J.F.; Pretty, J.; Robinson, S.; Thomas, S.M.; Toulmin, C. Food security: The challenge of feeding 9 billion people. Science 2010, 327, 812-818. [CrossRef]

2. FAO. The State of World Fisheries and Aquaculture 2020. Sustainability in Action; Food and Agriculture Organization of the United Nations: Rome, Italy, 2020.

3. Rosales, R.M.; Pomeroy, R.; Calabio, I.J.; Batong, M.; Cedo, K.; Escara, N.; Facunla, V.; Gulayan, A.; Narvadez, M.; Sarahadil, M.; et al. Value chain analysis and small-scale fisheries management. Mar. Policy 2017, 83, 11-21. [CrossRef]

4. Dabat, M.-H.; Orlandoni, O.; Fabre, P. Bridging research and policy: Evidence based indicators on agricultural value chains to inform decision-makers on inclusiveness and sustainability. In Proceedings of the 166th EAAE Seminar Sustainability in the Agri-Food Sector, National University of Ireland, Galway, Ireland, 30-31 August 2018; pp. 1-15.

5. Dabat, M.-H.; Orlandoni, O.; Fabre, P. An innovative integrated frame to deliver knowledge to policy-makers on inclusiveness and sustainability of agricultural value chains. In Proceedings of the 12èmes Journées de Recherche en Sciences Sociales (JRSS) SFER-INRA-CIRAD, Nantes, France, 13-14 December 2018; p. 19.

6. Sarch, M.; Allison, E.H. Fluctuating Fisheries in Africa's Inland Waters: Well Adapted Livelihoods, Maladapted Management. In Proceedings of the 10th International Conference of the Institute of Fisheries Economics and Trade, Corvallis, OR, USA, 10-14 July 2000.

7. Belhabib, D.; Sumaila, U.R.; Le Billon, P. The fisheries of Africa: Exploitation, policy, and maritime security trends. Mar. Policy 2019, 101, 80-92. [CrossRef]

8. Obiero, K.; Meulenbroek, P.; Drexler, S.; Dagne, A.; Akoll, P.; Odong, R.; Kaunda-Arara, B.; Waidbacher, H. The contribution of fish to food and nutrition security in Eastern Africa: Emerging trends and future outlooks. Sustainibilty 2019, 11, 1631. [CrossRef]

9. AUC-NEPAD. Policy Framework and Reform Strategy for Fisheries and Aquaculture in Africa; African Union Commission and NEPAD Planning and Coordinating Agency: Johannesburg, South Africa, 2014.

10. WFFP. La Pêche Artisanale Continentale; The World Forum of Fishing Peoples: Kampala, Uganda, 2017.

11. UEMOA Atlas UEMOA de la pêche continentale. Programme régional de renforcement de la collecte des données statistiques des pêches dans les Etats membres. Available online: http:/ / sirs.agrocampus-ouest.fr/atlas_uemoa (accessed on 1 January 2021).

12. UEMOA. Rapport National Sur Les Enquêtes Cadres « Pêche Artisanale Continentale » MALI; West African Economic and Monetary Union (UEMOA): Abuja, Nigeria, 2013.

13. Poore, J.; Nemecek, T. Reducing food's environmental impacts through producers and consumers. Science 2018, 360, 987-992. [CrossRef] [PubMed]

14. ISO. ISO 14040 Environmental Management_Life Cycle Assessment_Principles And Framework; The International Standards Organisation: Geneva, Swizterland, 2006.

15. Schmidheiny, S.; Stigson, B. Eco-Efficiency: Creating More Value With Less Impact; World Business Council for Sustainable Development: Geneva, Swizterland, 2000. 
16. Avadí, A.; Vázquez-Rowe, I.; Fréon, P. Eco-efficiency assessment of the Peruvian anchoveta steel and wooden fleets using the LCA+DEA framework. J. Clean. Prod. 2014, 70, 118-131. [CrossRef]

17. Vázquez-Rowe, I.; Iribarren, D.; Moreira, M.T.; Feijoo, G. Combined application of life cycle assessment and data envelopment analysis as a methodological approach for the assessment of fisheries. Int. J. Life Cycle Assess. 2010, 15, 272-283. [CrossRef]

18. Avadí, A.; Adrien, R.; Aramayo, V.; Fréon, P. Environmental assessment of the Peruvian industrial hake fishery with LCA. Int. J. Life Cycle Assess. 2017. [CrossRef]

19. Tyedmers, P. Fisheries and Energy Use. Encycl. Energy 2004, 1, 784.

20. Greer, K.; Zeller, D.; Woroniak, J.; Coulter, A.; Winchester, M.; Palomares, M.L.D.; Pauly, D. Global trends in carbon dioxide (CO 2$)$ emissions from fuel combustion in marine fisheries from 1950 to 2016. Mar. Policy 2019, 107, 103382. [CrossRef]

21. Tyedmers, P.H. Salmon and Sustainability: The Biophysical Cost of Producing Salmon Through the Commercial Salmon Fishery and the Intensive Salmon Culture Industry; The University of British Columbia: Vancouver, BC, USA, 2000.

22. Avadí, A.; Fréon, P. A set of sustainability performance indicators for seafood: Direct human consumption products from Peruvian anchoveta fisheries and freshwater aquaculture. Ecol. Indic. 2014, 48, 518-532. [CrossRef]

23. Vázquez-Rowe, I.; Iribarren, D. Review of Life-Cycle Approaches Coupled with Data Envelopment Analysis: Launching the CFP + DEA Method for Energy Policy Making. Sci. World J. 2015, 2015, 1-10. [CrossRef] [PubMed]

24. Nemecek, T.; Dubois, D.; Huguenin-Elie, O.; Gaillard, G. Life cycle assessment of Swiss farming systems: II. Extensive and intensive production. Agric. Syst. 2011, 104, 233-245. [CrossRef]

25. Thanawong, K.; Perret, S.R.; Basset-Mens, C. Eco-efficiency of paddy rice production in Northeastern Thailand: A comparison of rain-fed and irrigated cropping systems. J. Clean. Prod. 2014, 73, 204-217. [CrossRef]

26. Ullah, A.; Perret, S.R.; Gheewala, S.H.; Soni, P. Eco-efficiency of cotton-cropping systems in Pakistan: An integrated approach of life cycle assessment and data envelopment analysis. J. Clean. Prod. 2016, 134, 623-632. [CrossRef]

27. Czyżewski, B.; Matuszczak, A.; Grzelak, A.; Guth, M.; Majchrzak, A. Environmental sustainable value in agriculture revisited: How does Common Agricultural Policy contribute to eco-efficiency? Sustain. Sci. 2021, 16, 137-152. [CrossRef]

28. Costa, M.P.; Schoeneboom, J.C.; Oliveira, S.A.; Viñas, R.S.; de Medeiros, G.A. A socio-eco-efficiency analysis of integrated and non-integrated crop-livestock-forestry systems in the Brazilian Cerrado based on LCA. J. Clean. Prod. 2018, 171, 1460-1471. [CrossRef]

29. Kuhn, L.; Balezentis, T.; Hou, L.; Wang, D. Technical and environmental efficiency of livestock farms in China: A slacks-based DEA approach. China Econ. Rev. 2020, 62, 101213. [CrossRef]

30. Vázquez-Rowe, I.; Villanueva-Rey, P.; Moreira, M.T.; Feijoo, G. Edible protein energy return on investment ratio (ep-EROI) for Spanish seafood products. Ambio 2014, 43, 381-394. [CrossRef]

31. Laso, J.; García-Herrero, I.; Margallo, M.; Vázquez-Rowe, I.; Fullana, P.; Bala, A.; Gazulla, C.; Irabien, Á.; Aldaco, R. Finding an economic and environmental balance in value chains based on circular economy thinking: An eco-efficiency methodology applied to the fish canning industry. Resour. Conserv. Recycl. 2018, 133, 428-437. [CrossRef]

32. Willison, J.H.M.; Côté, R.P. Counting biodiversity waste in industrial eco-efficiency: Fisheries case study. J. Clean. Prod. 2009, 17, 348-353. [CrossRef]

33. Kulak, M.; Nemecek, T.; Frossard, E.; Chable, V.; Gaillard, G. Life cycle assessment of bread from several alternative food networks in Europe. J. Clean. Prod. 2015, 90, 104-113. [CrossRef]

34. Vayssières, J.; Thévenot, A.; Acosta, I.; Vigne, M.; Tillard, E. A Participatory, Territory-rooted and Change-oriented Framework to Assess the Multi-criteria Contribution of an Agrifood Value Chain to Sustainable Development. Indones. J. Life Cycle Assess. Sustain. 2019, 1, 43-63.

35. Avadí, A.; Fréon, P.; Tam, J. Coupled Ecosystem/Supply Chain Modelling of Fish Products from Sea to Shelf: The Peruvian Anchoveta Case. PLoS ONE 2014, 9, e102057. [CrossRef] [PubMed]

36. Acosta-Alba, I.; Avadí, A. Mapping fisheries value chains to facilitate their sustainability assessment: Case studies in The Gambia and Mali. Mar. Policy 2021, under review.

37. Andres, L.; Alba, I.A.; Nicolay, G.; Oswald, M.; Zerbo, H. Analyse de la Chaîne de la Pêche Continentale en République du Mali; European Commission, Directorate-General for International Cooperation and Development: Brussels, Belgium, 2020.

38. Avadí, A.; Deme, M.; Mbaye, A.; Ndenn, J. Fisheries and Aquaculture Value Chain Analysis in The Gambia; European Commission, Directorate-General for International Cooperation and Development: Brussels, Belgium, 2020.

39. Avadí, A.; Henriksson, P.J.G.; Vázquez-Rowe, I.; Ziegler, F. Towards improved practices in Life Cycle Assessment of seafood and other aquatic products. Int. J. Life Cycle Assess. 2018, 23, 979-981. [CrossRef]

40. Cordeiro da Silva, C.d.A. Global trends on Inland Fishery; Universidade Federal do Rio Grande do Norte-UFRN: Natal, Brazil, 2017; pp. 1-52.

41. Avadí, A.; Vázquez-Rowe, I. First series of seafood datasets in ecoinvent: Setting the pace for future development. Int. J. Life Cycle Assess. 2019. [CrossRef]

42. Avadí, A.; Fréon, P. Life cycle assessment of fisheries: A review for fisheries scientists and managers. Fish. Res. 2013, 143, 21-38. [CrossRef]

43. Koch, P.; Salou, T. AGRIBALYSE ®: Rapport Méthodologique-Version 1.3; ART, INRA, ADEME: Angers, France, 2016.

44. Avadí, A. Screening LCA of French organic amendments and fertilisers. Int. J. Life Cycle Assess. 2020, 25, 698-718. [CrossRef] 
45. Wernet, G.; Bauer, C.; Steubing, B.; Reinhard, J.; Moreno-Ruiz, E.; Weidema, B. The ecoinvent database version 3 (part I): Overview and methodology. Int. J. Life Cycle Assess. 2016, 21, 1218-1230. [CrossRef]

46. Huijbregts, M.A.J.; Steinmann, Z.J.N.; Elshout, P.M.F.; Stam, G.; Verones, F.; Vieira, M.; van Zelm, R. Recipe2016: A Harmonized Life Cycle Impact Assessment Method at Midpoint and Endpoint Level. Report I: Characterisation; Department of Environmental Science, Radboud University: Nijmegen, The Netherlands, 2016.

47. VDI. Cumulative Energy Demand-Terms, Definitions, Methods of Calculation; Verein Deutscher Ingenieure: Düsseldorf, Germany, 1997.

48. Vázquez-Rowe, I.; Tyedmers, P. Identifying the importance of the "skipper effect" within sources of measured inefficiency in fisheries through data envelopment analysis (DEA). Mar. Policy 2013, 38, 387-396. [CrossRef]

49. Wijermans, N.; Boonstra, W.J.; Orach, K.; Hentati-Sundberg, J.; Schlüter, M. Behavioural diversity in fishing-Towards a next generation of fishery models. Fish Fish. 2020, 21, 872-890. [CrossRef]

50. Laso, J.; Margallo, M.; Serrano, M.; Vázquez-rowe, I.; Avadí, A.; Fullana, P.; Bala, A.; Gazulla, C.; Irabien, Á.; Aldaco, R. Introducing the Green Protein Footprint method as an understandable measure of the environmental cost of anchovy consumption. Sci. Total Environ. 2018, 621, 40-53. [CrossRef] [PubMed]

51. Funge-Smith, S.; Bennett, A. A fresh look at inland fisheries and their role in food security and livelihoods. Fish Fish. 2019, 20, 1176-1195. [CrossRef]

52. Neiland, E.A.; Chimatiro, S.; Khalifa, U.; Ladu, B.M.B.; Nyeko, D. Inland Fisheries in Africa; NEPAD: Abuja, Nigeria, 2005.

53. Fréon, P.; Avadí, A.; Vinatea, R.A.; Iriarte, F. Life cycle assessment of the Peruvian industrial anchoveta fleet: Boundary setting in life cycle inventory analyses of complex and plural means of production. Int. J. Life Cycle Assess. 2014, 19, 1068-1086. [CrossRef]

54. Avadí, A.; Vázquez-Rowe, I. Life Cycle Inventories of Wild Capture and Aquaculture; Ecoinvent Association: Zürich, Switzerland, 2019.

55. Hospido, A.; Tyedmers, P. Life cycle environmental impacts of Spanish tuna fisheries. Fish. Res. 2005, 76, 174-186. [CrossRef]

56. Ziegler, F.; Eichelsheim, J.L.; Emanuelsson, A.; Flysjö, A.; Ndiaye, V.; Thrane, M. Life Cycle Assessment of Southern Pink Shrimp Products from Senegal. An Environmental Comparison Between Artisanal Fisheries in the Casamance Region; FAO: Rome, Italy, 2009; Volume 1044, ISBN 9789251063026.

57. Fréon, P.; Durand, H.; Avadí, A.; Huaranca, S.; Orozco Moreyra, R. Life cycle assessment of three Peruvian fishmeal plants: Toward a cleaner production. J. Clean. Prod. 2017, 145, 50-63. [CrossRef]

58. Seafish Fishmeal and fish oil facts and figures. Seafish 2018, 35.

59. IFFO. IFFO Annual Report 2018; The Marine Ingredients Organisation: London, UK, 2018; Volume 4.

60. Gorez, B. West Africa: Fishmeal, Mealy Deal; ICSF International Collective in Support of Fishworkers: Tamil Nadu, India, 2018; Volume 78.

61. Tarbiya, L.M.O.; Mouhamédou, F.O. Etude Diagnostique de la Filière de la Farine et de L'huile de Poisson en Mauritanie et au Niveau et International; Laboratoire des Etudes Sociales et Economiques: Cansado, Mauritania, 2011.

62. Corten, A.; Braham, C.B.; Sadegh, A.S. The development of a fishmeal industry in Mauritania and its impact on the regional stocks of sardinella and other small pelagics in Northwest Africa. Fish. Res. 2017, 186, 328-336. [CrossRef]

63. Greenpeace. A Waste of Fish-Food Security under Threat from the Fishmeal and Fish Oil Industry in West Africa; Greenpeace: Amsterdam, The Netherlands, 2019.

64. Henriksson, P.J.G.; Zhang, W.; Nahid, S.A.A.; Newton, R.; Phan, L.T.; Dao, H.M.; Zhang, Z.; Jaithiang, J.; Andong, R.; Chaimanuskul, K.; et al. Final LCA Case Study Report Primary Data and Literature Sources Adopted in the SEAT LCA Studies; Sustaining Ethical Aquaculture Trade, 2014. Available online: https://www.researchgate.net/profile/Mohammad-Haque-27 /publication/317824479_Final_LCA_case_study_report-results_of_LCA_studies_of_Asian_aquaculture_systems_for_tilapia_ catfish_shrimp_and_freshwater_prawn/links/594cec450f7e9ba1ec4f7709/Final-LCA-case-study-report-results-of-LCAstudies-of-Asian-aquaculture-systems-for-tilapia-catfish-shrimp-and-freshwater-prawn.pdf (accessed on 1 January 2021).

65. Bosma, R.; Anh, P.T.; Potting, J. Life cycle assessment of intensive striped catfish farming in the Mekong Delta for screening hotspots as input to environmental policy and research agenda. Int. J. Life Cycle Assess. 2011, 16, 903-915. [CrossRef]

66. Fréon, P.; Avadí, A.; Marin Soto, W.; Negrón, R. Environmentally extended comparison table of large- versus small- and medium-scale fisheries: The case of the Peruvian anchoveta fleet. Can. J. Fish. Aquat. Sci. 2014, 71, 1459-1474. [CrossRef]

67. Notten, P.; Althaus, H.; Jayaram, N.; Läderach, A.; Town, C. Life Cycle Inventories of Road Freight-India and South Africa; Ecoinvent Association: Zürich, Switzerland, 2018.

68. Bove, A.; Hartmann, O.; Stokenberga, A.; Vesin, V.; Yedan, Y. Le Transport Routier en Afrique de l'Ouest et en Afrique Centrale; SSATP: Bamako, Mali, 2018.

69. Parker, R.W.R.; Blanchard, J.L.; Gardner, C.; Green, B.S.; Hartmann, K.; Tyedmers, P.H.; Watson, R.A. Fuel use and greenhouse gas emissions of world fisheries. Nat. Clim. Chang. 2018, 8, 333-337. [CrossRef]

70. Parker, R.W.R.; Tyedmers, P.H. Fuel consumption of global fishing fleets: Current understanding and knowledge gaps. Fish Fish. 2014. [CrossRef]

71. World Bank. Hidden Harvest The Global Contribution of Capture Fisheries; World Bank: Washigton, DC, USA, 2012.

72. FAO/WHO/UNU. Energy and Protein Requirements; World Health Organization: Geneva, Swizterland, 1985.

73. FAO. Yield and Nutritional Value of the Commercially More Important Fish Species; Aberdeen, Torry Research Station and Rome; FAO: Rome, Italy, 1989. 
74. Vincent, A.; Grande, F.; Compaoré, E.; Amponsah Annor, G.; Addy, P.A.; Aburime, L.C.; Ahmed, D.; Bih Loh, A.M.; Dahdouh Cabia, S.; Deflache, N.; et al. FAO/INFOODS Food Composition Table for Western Africa. User Guide E Condensed Food Composition Table; Food and Agriculture Organization of the United Nations: Rome, Italy, 2020; ISBN 9789251322239.

75. FAO. Shark Utilization, Marketing and Trade; Food and Agriculture Organization of the United Nations: Rome, Italy, 2002.

76. FAO FAO/INFOODS. Global Food Composition Database for Fish and Shellfish-Version 1.0 (Ufish1.0); FAO: Rome, Italy, 2016.

77. Lelieveld, J.; Klingmüller, K.; Pozzer, A.; Burnett, R.T.; Haines, A.; Ramanathan, V. Effects of fossil fuel and total anthropogenic emission removal on public health and climate. Proc. Natl. Acad. Sci. USA 2019, 116, 7192-7197. [CrossRef]

78. Vázquez-Rowe, I.; Ita-Nagy, D.; Kahhat, R. Microplastics in fisheries and aquaculture: Implications to food sustainability and safety. Curr. Opin. Green Sustain. Chem. 2021, 29, 100464. [CrossRef]

79. Woods, J.S.; Verones, F.; Jolliet, O.; Vázquez-Rowe, I.; Boulay, A.-M. A framework for the assessment of marine litter impacts in life cycle impact assessment. Ecol. Indic. 2021, 129. [CrossRef]

80. Adeyeye, S.A.O.; Oyewole, O.B. An Overview of Traditional Fish Smoking In Africa. J. Culin. Sci. Technol. 2016, 14, 198-215. [CrossRef]

81. Allison, E.H.; Horemans, B. Putting the principles of the Sustainable Livelihoods Approach into fisheries development policy and practice. Mar. Policy 2006, 30, 757-766. [CrossRef]

82. Kirui, O.; Kozicka, M. Vocational Education and Training for Farmers and Other Actors in the Agri-Food Value Chain in Africa; Center for Development Research, University of Bonn: Bonn, Germany, 2018.

83. FAO. Guiding Principles for Promoting Aquaculture in Africa: Benchmarks for Sustainable Development; Food and Agriculture Organization of the United Nations: Rome, Italy, 2006.

84. ICSF. Report of the Study on Problems and Prospects of Artisanal Fish Trade in West Africa; International Collective in Support of Fishworkers (ICSF): Tamil Nadu, India, 2002.

85. Watson, R.A.; Cheung, W.W.L.; Anticamara, J.A.; Sumaila, R.U.; Zeller, D.; Pauly, D. Global marine yield halved as fishing intensity redoubles. Fish Fish. 2013, 14, 493-503. [CrossRef]

86. Belhabib, D.; Greer, K.; Pauly, D. Trends in Industrial and Artisanal Catch Per Effort in West African Fisheries. Conserv. Lett. 2018, 11, 1-10. [CrossRef]

87. Kroodsma, D.A.; Mayorga, J.; Hochberg, T.; Miller, N.A.; Boerder, K.; Ferretti, F.; Wilson, A.; Bergman, B.; White, T.D.; Block, B.A.; et al. Tracking the global footprint of fisheries. Science 2018, 908, 904-908. [CrossRef] [PubMed]

88. Vannuccini, S. Enhancing Fishery and Aquaculture Data to Achieve the Sdgs-Achievements And Challenges; FAO Fishery and Aquaculture Department: Rome, Italy, 2019.

89. Bertrand, A.; Lengaigne, M.; Takahashi, K.; Avadí, A.; Poulain, F.; Harrod, C. El Niño Southern Oscillation (ENSO) Effects on Fisheries and Aquaculture; Food and Agriculture Organization of the United Nations: Rome, Italy, 2020.

90. Laë, R.; Mahé, G. Crue, inondation et production halieutique. Un modèle prédictif des captures dans le delta intérieur du Niger. In Gestion Intégrée des Zones Inondables Tropicales; Orange, D., Arfi, R., Kuper, M., Morand, P., Poncet, Y., Eds.; Éditions IRD: Paris, France, 2002; pp. 865-884.

91. Laë, R. Influence de l'hydrologie sur l'évolution des pêcheries du delta central du Niger, de 1966 à 1989. Aquat. Living Resour. 1992, 5, 115-126. [CrossRef]

92. Kruijssen, F.; Avadí, A.; Cole, S.; Mungule, C.M.; van Duijn, A. Aquaculture Value Chain Analysis in Zambia; European Commission, Directorate-General for International Cooperation and Development: Brussels, Belgium, 2018.

93. Sililo, S.; Musuka, C.G.; Kefi, A.S. Fish Imports and Their Contribution towards Feeding an Ever-Growing Population in Zambia. Innov. Tech. Agric. 2017, 1, 107-115.

94. Gordon, A.; Finegold, C.; Charles, C.; Pulis, A. FIsh Production, Consumption, and Trade in Sub-Saharan Africa: A Review Analysis; WorldFish: Penang, Malaysia, 2013.

95. Abila, R.O. Impacts of International Fish Trade: A Case Study of Lake Victoria Fisheries. Fish. Tech. Pap. $2005,61$.

96. Hara, M.; Greenberg, S.; Chimatiro, S.; Toit, A. Du, Trade and Investment in Fish and Fish Products between South Africa and the Rest of SADC: Implications for Food and Nutrition Security; Institute of Poverty, Land and Agrarian Studies: Bellville, South Africa, 2017.

97. Ragasa, C.; Andam, K.S.; Kufoalor, D.S.; Amewu, S. A Blue Revolution in sub-Saharan Africa? Evidence from Ghana's Tilapia Value Chain; IFPRI: Accra, Ghana, 2018; p. 31.

98. Genschick, S.; Kaminski, A.M.; Kefi, A.S.; Cole, S.M. Aquaculture in Zambia: An Overview and Evaluation of the Sector's Responsiveness to the Needs of the Poor; CGIAR Research Program on Fish Agri-Food Systems: Penang, Malaysia; Department of Fisheries: Lusaka, Zambia, 2017.

99. Efole Ewoukem, T.; Aubin, J.; Mikolasek, O.; Corson, M.S.; Tomedi Eyango, M.; Tchoumboue, J.; Van Der Werf, H.M.G.; Ombredane, D. Environmental impacts of farms integrating aquaculture and agriculture in Cameroon. J. Clean. Prod. 2012, 28, 208-214. [CrossRef] 